\title{
Kaolin Clay Reinforced with a Granular Column Containing Crushed Waste Glass or Traditional Construction Sands
}

1. Danish Kazmi (corresponding author)

Affiliation

Geotechnical Engineering Centre, School of Civil Engineering, The University of Queensland, Brisbane, QLD 4072, Australia

Positions

Research Scholar

Email address

d.kazmi@uq.net.au

2. Mehdi Serati

Affiliation

Geotechnical Engineering Centre, School of Civil Engineering, The University of Queensland, Brisbane, QLD 4072, Australia

Position

Lecturer

Deputy Manager, Large Open Pit Project (www.lopproject.com)

Email address

m.serati@uq.edu.au

3. David J. Williams

\section{Affiliation}

Geotechnical Engineering Centre, School of Civil Engineering, The University of Queensland, Brisbane, QLD 4072, Australia

Position

Professor of Geotechnical Engineering

Director, Geotechnical Engineering Centre

Manager, Large Open Pit Project (www.lopproject.com)

MWT 2020 Conference Chair

Email address

d.williams@uq.edu.au

4. Sebastian Quintero Olaya

Affiliation

Geotechnical Engineering Centre, School of Civil Engineering, The University of Queensland, Brisbane, QLD 4072, Australia

Position

Senior Research Officer

Email address

s.quintero@uq.edu.au

5. Sadaf Qasim

Affiliation

Department of Civil Engineering, NED University of Engineering and Technology, Karachi, 75270, Pakistan

Position

Associate Professor

Email address

erum@neduet.edu.pk 


\section{Yi Pik Cheng}

\section{Affiliation}

Department of Civil, Environmental and Geomatic Engineering, University College London, London, WC1E 6BT, United Kingdom

Position

Senior Lecturer

Email address

yi.cheng@ucl.ac.uk

\section{J. Antonio H. Carraro}

\section{Affiliation}

Department of Civil and Environmental Engineering, Imperial College London, London, SW7 2AZ, United Kingdom

Position

Senior Lecturer in Experimental Geotechnical Engineering

Email address

antonio.carraro@imperial.ac.uk

\section{Abstract}

Installation of granular columns is a cost-effective and versatile in situ technique to improve the shear strength, settlement, and drainage behaviour of weak soils. It involves backfilling vertical boreholes in the ground with granular materials stiffer than the native soil, such as stone or compacted sand. However, the massive use and overexploitation of sand and natural aggregates have depleted their reserves in recent decades, causing damage to the environment, creating sand shortages and skyrocketing their price. Hence, it is essential to develop a sustainable alternative to natural aggregates to construct granular columns. The ever-increasing stockpiles of waste glass could be a potential replacement for natural sand in several geotechnical construction applications, noting that both materials have a similar chemical composition. Using crushed waste glass (CWG) as an alternative to traditional natural and manufactured (quarried) sands in granular columns could offer a multipronged benefit by recycling non-biodegradable waste (glass) and by conserving a depleting natural resource (sand). Using a large direct shear (LDS) machine, this study investigated the shear strength behaviour of kaolin (to represent a typical weak soil) reinforced with a central granular column. Three different materials were separately used to backfill the column, including natural sand (NS), manufactured sand (MS) and CWG. The results revealed that the geocomposites containing the CWG 
80

81

82

83

84

85

86

87

88

89

90

91

92

93

94

95

96

97

98

99

100

101

102

103

104

105

106

107

108

109

110

111

112

113

114

115

116

117

118

119

120

121

122

column have the highest peak friction angle and relatively greater shear strength under high normal stresses, favouring the potential use of CWG as a green alternative to traditional sands in backfilling granular columns, ultimately supporting resource conservation, waste recycling and the paradigm shift towards a circular economy.

\section{Keywords}

Granular columns; natural aggregates; crushed waste glass; large direct shear machine; shear strength; geocomposites; circular economy

88

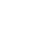

(1)

(1)

(

(9)

(95

8

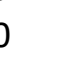

2

4

6

8

(1)

.

4

(1)

7

(1)

120


As cities grow, the need to develop low-lying and coastal areas inevitably increase. Low-lying lands are often overlain by soft or loose soils, which are highly compressible and typically marked by low shear strength Malarvizhi (2007), requiring ground improvement before the foundations for new infrastructure could be constructed (Alfaro et al., 1994). Similar challenges are sometimes encountered for inland sand deposits due to water fluctuations in the soil caused by weather changes (Sivakumar et al., 2014). Poor ground properties could be detrimental to infrastructures. For example, the annual damage caused by expansive soils to civil engineering structures is around $\$ 1,000$ million in the USA, \$150 million in the UK and at least $\$ 4$ million in South Africa (Gourley et al., 1993). The growing land prices and the limited availability of suitable construction sites encourage the need for ground improvement (Babu et al., 2013). Several ground improvement techniques have been developed to improve the geotechnical characteristics of weak in situ soils, such as bearing capacity and settlement (Andreou et al., 2008).

Of all the ground improvement techniques available, granular columns, also known as sand or stone columns, granular piles or granular inclusions, are considered one of the most cost-effective and versatile in situ ground improvement techniques whose concept was first applied in France in 1830 (Babu et al., 2013). In this technique, vertical boreholes are formed in the soil that are filled upwards with compacted granular backfill such as sand or stone (Castro, 2017). They can be used to improve several types of soil, from soft clays to loose sands, making them one of the preferred ground improvement techniques (Abhishek et al., 2016). They also serve as vertical drains and dissipate excess pore water pressure due to loading by providing a shorter drainage path of higher permeability, thereby increasing the consolidation rate and reducing the time required for post-construction ultimate settlements (Abhishek et al., 2016; McCabe et al., 2007). Another key benefit of granular columns is the densification of the in situ soil surrounding the columns, which enhances the compaction characteristics of the in situ soil (Ranjan, 1989). Moreover, granular columns could 
effectively mitigate potential liquefaction or softening of susceptible soils through reinforcement, drainage and densification (Abhishek et al., 2016).

150

151

152

According to Sivakumar et al. (2004), a granular column develops end-bearing pressure and shear stresses when loaded vertically, causing the column to expand laterally and mobilise lateral support from the surrounding soil. This increase in lateral stress consolidates the surrounding clay once the excess pore water pressure dissipates and causes further bulging in the column. This process continues until equilibrium is achieved at the boundary between the column and the surrounding clay. As a result, the column and the surrounding clay act as a composite with a higher stiffness than the original soil (Mohapatra et al., 2014). The net result is that the entire site where the columns are installed then displays higher strength, improved bearing capacity and stiffness. Technically, granular columns largely obtain their load capacity from the confinement provided by the surrounding soil by mobilising passive earth pressure (Babu et al., 2013). However, for very soft clays with very low undrained shear strength $\left(<15 \mathrm{kN} / \mathrm{m}^{2}\right)$, such soils provide insufficient lateral confinement causing the columns to undergo excessive bulging and settlements that reduce the load-carrying capacity and the effectiveness of granular columns (Murugesan \& Rajagopal, 2007).

Granular columns are mostly installed using the vibro-flotation technique, whose typical installation process is schematically shown in Figure 1. A vibroflot (or vibrating poker) is inserted into the ground to create a vertical hole that is incrementally filled with compacted sand or stone (Ranjan, 1989). Vibro-replacement is generally used for clayey soils (Priebe, 1995). Moreover, granular columns are environment-friendly (Hanna et al., 2013; Mehrannia et al., 2018). They release relatively lower greenhouse gas emissions and consume relatively less fuel during their installation (Chawla et al., 2010).

Theoretically, the unit cell model is mostly used to analyse granular columns (Castro, 2017). It consists of a single column and its corresponding tributary area transformed into an equivalent circle (influence zone) with the same cross-sectional area (Ng \& Tan, 2015). The diameter of a unit cell is equal to $d_{e}=$ 
$1.05-1.13 \mathrm{~s}$ for triangular and square grids, respectively, where $s$ is the centre-to-centre spacing between columns (Castro, 2017). Several parameters influence the behaviour of soil reinforced with granular columns, including the area replacement ratio, length and diameter of the column, material properties of the column backfill, spacing between the columns and the installation pattern of the columns (Babu et al., 2013; Bergado et al., 1990; Poorooshasb \& Meyerhof, 1997; Priebe, 1995).

Several studies have examined the geotechnical performance of soil treated with granular columns. Some of these studies compared the shear resistance and load-settlement response of ordinary and geotextile-encased columns (e.g. Mohapatra et al. 2014, Malarvizhi 2007); however, they are not the focus of this study.

Canakci et al. (2017) investigated the shear strength (direct shear) and compressibility (oedometer) performance of fibrous peat soil (liquid limit of $119 \%$ ) reinforced with a sand column. Rounded poorlygraded sand, passing a 2-mm sieve and retained on a 1-mm sieve, was used to construct the column at three different area replacement ratios $(11.5 \%, 25 \%$ and $49 \%)$. Their study found that installing a sand column improved the peat's compressibility and shear strength behaviour, with compressibility characteristics improving with increase in the area replacement ratio.

Similarly, Najjar et al. (2010) examined the mechanical behaviour of normally consolidated clay (kaolin) reinforced with encased and non-encased sand columns. The sand columns comprised poorly graded Ottawa sand with a friction angle of $33^{\circ}$ and were installed at a relative density of nearly $44 \%$.

A total of 32 isotropically consolidated undrained (CU) triaxial tests was performed on reinforced specimens with area replacement ratios of $7.9 \%$ and $17.8 \%$. The study found that the sand columns considerably reduced the generation of excess pore water pressure during undrained loading. It was also noted that increasing the area replacement ratio from $7.9 \%$ to $17.5 \%$ considerably increased the undrained shear strength of kaolin reinforced with fully-penetrating non-encased sand columns. 
Aslani et al. (2019) investigated the shear strength behaviour of clay reinforced with granular columns containing gravel $\left(D_{50}=0.52 \mathrm{~mm}\right)$ or stone $\left(D_{50}=4.2 \mathrm{~mm}\right)$. Using a large direct shear machine with an area of $305 \mathrm{~mm} \times 305 \mathrm{~mm}$ and depth of $152.4 \mathrm{~mm}$, tests were performed on geocomposites containing three different area replacement ratios $(13.3 \%, 17.7 \%$ and $24 \%)$, different installation patterns (single, square and triangular) and different normal stresses (35 kPa, $55 \mathrm{kPa}$ and $75 \mathrm{kPa}$ ). Their study concluded that the shear strength of the geocomposites increased with increasing area replacement ratio in all granular column installation patterns. The study also observed that installing a granular column increased the stiffness of reinforced clay compared to the unreinforced clay.

Barmade et al. (2021) investigated the load-settlement behaviour of expansive soil reinforced with stone columns with diameters of $40 \mathrm{~mm}, 60 \mathrm{~mm}$ and $80 \mathrm{~mm}$. Their study concluded that installing stone columns improved the bearing pressure of the reinforced soil, while the columns also increased the drainage of the soil. Hence, the benefits of installing granular columns in weak soils are wellestablished in the literature, as discussed in the reviewed studies (Babu et al., 2013; Manohar \& Patel, 2021; Mokhtari \& Kalantari, 2012; Najjar, 2013).

Why should the crushed waste glass be considered for use as an alternative to traditional construction sands?

Natural aggregates are fundamentally used to create granular columns. However, due to the continued use and heavy reliance of the construction industry, the aggregates (sand and stone) suitable for construction are rapidly depleting globally (Holmstrom \& Swan, 1999; Kazmi et al., 2020c; Kazmi et al., 2019a). Studies show that sand and gravel are being mined at a rate greater than their renewal (Bendixen et al., 2019). As a result, the global demand for natural sand and gravel has skyrocketed to almost 50 billion tonnes per year, averaging $18 \mathrm{~kg} /$ person/day (UNEP, 2019). Today many countries in the world face an approaching risk of a shortage of aggregates (Langer et al., 2004). Simultaneously, the mining of aggregates and associated activities typically releases a carbon footprint that is harmful to the environment (Bravo et al., 2015; Kazmi et al., 2020b). Thus, there is a growing 
need to develop a sustainable replacement for natural and manufactured (quarried) sands in construction, including geotechnical applications (Kazmi et al., 2019b). The ever-increasing volumes of waste glass could provide such an alternative (Kazmi et al., 2021). Nearly 10, 15 and 1 million tons of waste glass are stockpiled every year in United States, European Union and Australia, respectively, creating a challenge for their safe and sustainable disposal (Saberian et al., 2019). According to Kazmi et al. (2019a), given the growing quantities of waste glass and diminishing reserves of natural sand, the use of waste glass as an alternative to natural and manufactured (quarried) sand could provide two-pronged benefits of economy and environmental sustainability. In cities, waste glass is typically produced in greater volumes, and quarries are often far from project sites. Using crushed waste glass (CWG) as an alternative geomaterial could be cost-effective due to low material cost, reduced travel distance and shorter transportation time. Simultaneously, as waste glass is non-biodegradable, such utlisation of CWG could promote waste recycling, decrease burden on landfills, reduce greenhouse gas emissions and conserve natural raw materials, ultimately all leading towards a circular economy.

\section{Common safety concerns associated with the use of crushed waste glass}

Generally, a common safety concern associated with using CWG is the risk of skin cut due to sharp edges of glass particles (Ali, 2012). However, practical experience suggests that glass particles finer than $19 \mathrm{~mm}$ poses no greater cut or penetration risk than an ordinary fractured natural aggregate (Ali, 2012). Another common concern about the use of glass is the risk of contracting silicosis, a respiratory disease caused when crystalline silica is inhaled. However, during the glass manufacturing process, the crystalline silica is largely turned into amorphous silica, which does not primarily lead to silicosis (Clean Washington Center, 1996). Moreover, previous studies show that CWG could be a potential replacement for natural sand in several geotechnical construction applications (Wartman et al., 2004; Disfani et al., 2011; Arulrajah et al., 2013). Kazmi et al. (2020a) compared the geotechnical, mineralogical and morphological behaviour of CWG with those of natural sand (NS) and manufactured sand (MS). Their study concluded that CWG has geotechnical behaviour similar to traditional 
construction sands and could potentially be used as an alternative smart geomaterial in several geotechnical construction applications (Kazmi et al., 2020a).

Use of alternative geomaterials in granular columns

Granular columns offer an ideal opportunity to utilise recycled aggregates as column backfill (Egan \& Slocombe, 2010). However, limited research is done on using alternative materials (waste) to backfill granular columns (Ayothiraman \& Soumya, 2015). A few researchers observed some favourable behaviour of granular columns backfilled with different alternative materials, including tyre chips, recycled crushed brick, recycled crushed concrete, recycled railway track ballast, incinerator bottom ash aggregate (IBAA) and construction and demolition waste (Alnunu \& Nalbantoglu, 2019; Amini, 2016; Ayothiraman \& Soumya, 2015; Kumar \& Sadana, 2012; Serridge, 2004; Serridge \& Sarsby, 2009; Shahverdi \& Haddad, 2020). However, despite enormous potential, no detailed study has been found to date investigating the use of CWG as backfill in granular columns.

To fill this research gap, this study investigates the shear strength behaviour of geocomposites (soil reinforced with a granular column) with a granular column containing CWG and installed in the centre of a weak clayey soil (kaolin). Several reasons led to the selection of kaolin as the weak soil in this study. Firstly, kaolin has relatively low shear strength and often requires some form of treatment or reinforcement to support applied loads. Also, kaolin is readily available commercially, and its information database is extensive due to the large number of studies involving its use (Mishra et al., 2018a; Mishra et al., 2018b; Mishra et al., 2020; Rossato et al., 1992). The novelty of this paper is that it compares the shear strength behaviour of geocomposites containing a CWG column with those containing a column made up of NS or MS, which are traditionally used in sand column construction (Zukri and Nazir, 2018).

\section{Methodology}

In this study, a series of large direct shear tests (LDST) on cubical specimens with length, width and height equal to $150 \mathrm{~mm}$ were performed to investigate the shear strength behaviour of 
geocomposites. Each geocomposite comprised of a cubical kaolin clay specimen (bed material) with a vertical granular column installed in its centre. Distinct geocomposites were prepared using columns containing three different types of column backfill. The LDS tests were also performed on kaolin as a control sample to compare its shear strength behaviour with that of column-kaolin geocomposites. Three different materials were separately used to backfill the granular column, including NS, MS or CWG.

Table 1 shows the results of the mineralogical analysis performed on NS, MS and CWG using X-ray fluorescence (XRF) spectroscopy, showing that silica $\left(\mathrm{SiO}_{2}\right)$ is the dominant mineral in all three materials. Table 2 presents the geotechnical characterisation results of all the test materials, as reported by Kazmi et al. (2021) and Xu et al. (2018), showing that NS and CWG are uniformly graded materials with median particle sizes of $0.29 \mathrm{~mm}$ and $1.42 \mathrm{~mm}$, respectively. The median particle size of NS is almost five times smaller than that of CWG. MS, however, is a well-graded sand with a median particle size of $1.55 \mathrm{~mm}$. Figure 3 illustrates the gradation curves of the test materials.

The morphological analysis showed that MS has the highest particle angularity, followed by CWG and NS. This implies that NS particles are relatively more rounded than MS and CWG particles. Figure 2 shows the optical microscopic images of NS, MS and CWG particles. Also, the permeability tests revealed that CWG has the highest permeability, followed by NS and MS. CWG has the lowest minimum dry density and the largest difference between maximum and minimum dry density values. The critical-state friction angle of CWG increased by almost $11 \%$, from $29.1^{\circ}$ under dry conditions to $32.4^{\circ}$ under saturated conditions.

The kaolin used in this study is a highly plastic clay $(\mathrm{CH})$ with a liquid limit and plasticity index of $90 \%$ and $55 \%$, respectively. The percentage of material passing the $\# 200$ sieve $\left(F_{200}\right)$ is $69 \%$ for the kaolin.

The advanced high-accuracy large direct shear test machine (LDSM), ADS-300, manufactured by Wille Geotechnik in Germany, was used to test the shear strength of all the specimens. The machine is 
equipped with four linear variable differential transducers (LVDTs) on four corners of the top-loading

297

298

299

300

301

302

303

304

305

306

307

308

309

310

311

312

313

314

315

316

317

318

cap, recording the average settlement value. The testing setup also features a computer with data logging software to precisely record the measurements. The size of all the geocomposites tested was $150 \mathrm{~mm} \times 150 \mathrm{~mm} \times 150 \mathrm{~mm}$. A key reason to use the LDSM is that it provides the ability to test relatively large specimens alongside better control over specimen design parameters. This helps in minimising the size effect and modelling the field conditions more accurately. The device also monitors tilting through the four LVDTs, making tests more accurate. If the tilting exceeds $10 \%$ of the specimen height, the machine stops automatically. The LDSM used is capable of testing the specimens according to ASTM D3080-11 and BS 1377-7. Figure 4 shows the LDSM used.

The kaolin (Eckalite 1) used in this study is high-quality water washed china clay with controlled particle size distribution and colour, manufactured under a quality system certified facility. For sample preparation, the kaolin was mixed with water using a mechanical mixer and prepared at an average water content, consistency index and liquidity index of 56\%, 0.61 and 0.38 , respectively. The undrained shear strength $\left(\mathrm{S}_{\mathrm{u}}\right)$, in $\mathrm{kPa}$, of kaolin was estimated to be approximately $29.3 \mathrm{kPa}$ using the following correlation proposed by Wroth \& Wood (1978):

$$
\mathrm{S}_{\mathrm{u}}=170 \times \exp (-4.6 \times \mathrm{LI})
$$

where, $\mathrm{LI}$ is the liquidity index of the soil.

Afterwards, the prepared kaolin was thoroughly mixed and soaked for at least 24 hours in an airtight container to ensure uniform water consistency. Necessary care was practised to prevent lumps from being left in the prepared kaolin. The dry density of the kaolin bed was set constant to $10 \mathrm{kN} / \mathrm{m}^{3}$ for all the specimens. The kaolin bed was prepared by compacting the pre-weighted kaolin in three equal layers spread and compacted evenly using a hand tamper to avoid any air entrapment between the layers of kaolin. The thickness of each kaolin layer was maintained at $50 \mathrm{~mm}$. Kaolin samples were taken from the leftover of kaolin bed every time the specimen was prepared to determine the most representative water content. 
With a column penetration ratio $\left(C_{r}\right)$, defined as the height of the column to the height of the

322

323

324 specimen, of 1.0, an end-bearing granular column was installed in the middle of the kaolin bed through the replacement method. A thin-walled polyvinyl chloride (PVC) tube, with a thickness of $2.5 \mathrm{~mm}$ and an external diameter of $68 \mathrm{~mm}$, was used to construct the granular column. The end-bearing column was created because the increase in column length significantly improves the behaviour of reinforced soil, mainly due to sufficient mobilisation of end-bearing capacity and skin resistance through an increase in the peripheral area and overburden stress (Dash \& Bora, 2013). An adequate gap was maintained between the shear box and the boundaries of the granular column to avoid the boundary effect during the test. The PVC tube was gradually pushed vertically and concentrically into the kaolin bed until it reached the bottom of the shear box. A static force was applied to drive the PVC tube into the kaolin to minimise the disturbance in the surrounding kaolin. After installing the PVC tube, the kaolin within the tube was scooped out using a stainless steel spatula. All the geocomposites were prepared at an area replacement ratio $\left(A_{r}\right)$ of $16 \%$. $A_{r}$ is defined as the plan area of the column to the plan area of the shear box. This $A_{r}$ was selected to avoid the influence of the shear box boundary on the results. The column's length to diameter (L/D) ratio was 2.2, ensuring that the column was within its critical length. The pre-weighed quantity of oven-dried granular backfill was carefully charged into the resulting hole using a funnel. The column backfill was compacted in three different layers using a hand tamper to achieve a relative density (or density index) of $60 \%$. This relative density was adopted to ensure there was no lateral bulging of the column to avoid disturbance to the surrounding kaolin. Another reason for choosing this relative density was to pick a value that correlates with the practical conditions. The column backfill was compacted till both kaolin and column reached the same height. Afterwards, the cylindrical PVC tube was gradually withdrawn from the kaolin bed by carefully pulling it upwards. Samples were taken from the leftover of the prepared kaolin bed just before starting the LDS test to perform the water content testing. The shearing plane was situated in the middle of the sample (at $75 \mathrm{~mm}$ height). Overall, this procedure was found to give repeatable and uniform 
specimens of good quality. The typical plan and cross-section of the geocomposite are shown in Figure $5 a$ and $5 b$, respectively.

The single-stage (implying that a new specimen was prepared for test under each load) stresscontrolled LDS experiments were performed on the prepared kaolin specimens and geocomposites. The geocomposites were tested separately under $12.5 \mathrm{kPa}, 25 \mathrm{kPa}, 50 \mathrm{kPa}$ and $100 \mathrm{kPa}$ normal stress, with the normal stress increasing at a load increment factor of 1.0. All the geocomposites and kaolin specimens were consolidated under each normal stress before shearing them uniformly at a slow rate of $0.02 \mathrm{~mm} / \mathrm{min}$ to allow the column to mobilise its drainage capacity. The specimens were allowed to drain water and were not inundated during the test. The test was stopped when the shear stress became constant, or the shear displacement reached $28 \mathrm{~mm}$ (18\% shear strain). The stress and displacement data were continuously recorded using the LVDT and computerised data acquisition system. Altogether, sixteen LDS tests were performed. Figure $6 a, 6 b, 6 c$ and $6 d$ represents the top view of the kaolin specimen, the NS-kaolin, the MS-kaolin and the CWG-kaolin geocomposite before the test respectively.

\section{Experimental results}

The obtained results were used to develop the shear strength envelopes that were best-fitted using the Coulomb failure criterion. The peak shear strength from each experiment was plotted against the corresponding normal stress to develop the envelope. The shear strength of all the specimens was found to increase with normal stress. The applied normal stresses and measured shear stresses were corrected for reductions in the shearing area during the specimen shearing. The fitting parameters for each envelope were determined in terms of the coefficient of determination $\left(R^{2}\right)$ and the NashSutcliffe model efficiency coefficient (NSE). Given the criteria proposed by Chiew \& McMahon (1993), the goodness-of-fit of all shear strength envelopes presented in this paper can be rated as "perfect" (NSE $\geq 0.93$ ). Table 3 shows the peak friction angle of the kaolin specimens and the geocomposites. Figure 7 shows the peak shear strength envelopes of the kaolin and the geocomposites. 
The results show that the cohesion of kaolin is $1.7 \mathrm{kPa}$, whereas its friction angle is $14.0^{\circ}$. Overall, installing a granular column increased the shear strength of the geocomposite, regardless of the type of column backfill used. The shear strength parameters of kaolin were considered as a reference for comparison.

The results of the NS-kaolin geocomposite showed that installing the NS column increased the friction angle from $14.0^{\circ}$ to $17.8^{\circ}$, an increase of $27 \%$, whereas the cohesion increased over two-fold from 1.7 $\mathrm{kPa}$ to $3.9 \mathrm{kPa}$. Compared to the kaolin specimens, the increase in the friction angle of the NS-kaolin geocomposite appears largely due to the inclusion of the NS column, as the characterisation testing previously showed that NS has a peak friction angle of $36.9^{\circ}$ under dry conditions. It is postulated that the NS-kaolin geocomposite derives its cohesion ( $3.9 \mathrm{kPa}$ ) from two parts: the true cohesion of kaolin and the apparent cohesion of NS.

The results of the MS-kaolin geocomposite showed an increase in both the cohesion and friction angle. The friction angle of the MS-kaolin geocomposite increased to $17.7^{\circ}$, an increase of $26 \%$, which is similar to that of the NS-kaolin geocomposite. However, the MS column considerably increased the cohesion of the geocomposite to $5.4 \mathrm{kPa}$, an increase of over three-fold. Also, the peak shear strength of the MS-kaolin geocomposite was higher than that of the NS-kaolin geocomposite under all the applied normal stresses. The reason for the higher peak shear strength of the MS-kaolin geocomposite compared with that of the NS-kaolin geoomposite could be the more well-graded MS, its higher particle angularity and its larger median particle size.

The results of the CWG-kaolin geocomposite showed a two-fold increase in cohesion compared with kaolin alone, which is somewhat similar to that of the NS-kaolin geocomposite. Importantly, installing the CWG column showed the highest increase in friction angle, increasing from $14.0^{\circ}$ for kaolin alone to $20.7^{\circ}$. The reason for the relatively higher friction angle of the CWG-kaolin geocomposite and lower cohesion could be the higher Young's Modulus of the CWG particles. The Young's Modulus of CWG is nearly $45 \mathrm{Gpa}$ (Hsieh et al., 2009; University of Texas, 2019), whereas that of sands and gravels varies 
from 10-170 MPa (University of Texas, 2019). The higher Young's Modulus of CWG potentially attracts

397

398

399

400

401

402

403

404

405

406

407

408

409

410

411

412

413

414

415

416

417

418

419

420

greater stress to the CWG column, leading to more stress being taken by the CWG column than the kaolin. As a result, the granular characteristics of the geocomposite become more dominant during shearing.

Figures $8 \mathrm{a}$ and $9 \mathrm{a}$ present the shear stress-horizontal displacement and horizontal-vertical displacement behaviour of kaolin alone, respectively. Figures $8 \mathrm{~b}, 8 \mathrm{c}$ and $8 \mathrm{~d}$ present the shear stresshorizontal displacement behaviour of NS-kaolin, MS-kaolin and CWG-kaolin geocomposites, respectively. Similarly, Figures $9 b, 9 c$ and $9 d$ present the horizontal-vertical displacement behaviour of NS-kaolin, MS-kaolin and CWG-kaolin geocomposites, respectively. The shear stress-horizontal displacement behaviour of the kaolin specimens showed that the shear stress non-linearly increased with an increase in shear displacement. The horizontal-vertical displacement behaviour of the kaolin specimens showed progressively higher vertical displacement with increasing normal stress, with over $10 \mathrm{~mm}$ compression observed under $100 \mathrm{kPa}$ normal stress. It was also noted that the amount of vertical displacement during shearing under higher normal stress (100 $\mathrm{kPa})$ was highest in kaolin alone compared to all of the geocomposites.

The shear stress-horizontal displacement behaviour of the NS-kaolin geocomposite showed a clear peak in shear stress under $100 \mathrm{kPa}$ normal stress. The horizontal-vertical displacement behaviour of the NS-kaolin geocomposite showed that the lowest and highest vertical displacement occurred under $100 \mathrm{kPa}$ and $50 \mathrm{kPa}$ normal stress, respectively. A sharp drop in vertical stress was also noted in the NS-kaolin geocomposite at approximately $17 \mathrm{~mm}$ horizontal displacement under $12.5 \mathrm{kPa}$ normal stress. This drop in vertical displacement would have densified the specimen, leading to a slight increase in shear stress. The MS-kaolin geocomposite showed two distinct rises and falls in shear stress between 1-3 mm horizontal displacement under $50 \mathrm{kPa}$ normal stress, possibly due to the dispersion of microcracks or rearrangement of sand particles. Another potential reason for these sudden changes could be that some sand particles at the column-kaolin interface started to penetrate the kaolin, 
leading to a sudden drop in shear stress. When the smear zone was created, the shear stress started increasing again (Xu et al., 2018).

The horizontal-vertical displacement behaviour of the MS-kaolin geocomposite showed a drop in vertical displacement between $12-13 \mathrm{~mm}$ and $20-21 \mathrm{~mm}$ horizontal displacement under $12.5 \mathrm{kPa}$ normal stress. This drop in vertical displacement would have densified the MS-kaolin geocomposite, increasing the shear stress at these horizontal displacements, as for the NS-kaolin geocomposite. Also, the shear stress-horizontal displacement behaviour of the CWG-kaolin geocomposite showed a relatively higher increase in shear stress with increasing normal stress. A sharp rise and fall in shear stress were also observed between 3-4 mm horizontal displacement under $50 \mathrm{kPa}$ normal stress, possibly due to localised strain-softening, which is somewhat comparable to the MS-kaolin geocomposite results. Figure $9 \mathrm{~d}$ shows a relatively smooth, non-linear and comparable horizontalvertical displacement behaviour under $12.5 \mathrm{kPa}, 25 \mathrm{kPa}$ and $100 \mathrm{kPa}$ normal stress, with relatively much higher vertical displacement under $50 \mathrm{kPa}$ normal stress.

For all three geocomposites, the highest vertical displacement was observed under $50 \mathrm{kPa}$ normal stress, with the vertical displacement reducing under $100 \mathrm{kPa}$. The potential reason for this could be greater stress concentration on the column under higher normal stresses, reducing the kaolin's contribution to shear strength and allowing the column to dominate the system.

Figure 10 compares the maximum vertical displacement (compression) of all the specimens during shearing with their corresponding applied normal stress. It can be seen that the significant reduction in the maximum vertical displacement (less compression) occurs under the applied normal stress of $100 \mathrm{kPa}$ for all three geocomposites, potentially due to higher stress concentration on the column under $100 \mathrm{kPa}$ applied normal stress, which is the highest normal stress applied in this study.

\section{Discussion}

444 Typically, clays are highly sensitive to variation in their water content Spoor and Godwin (1979), and are marked by lower shear strength (Aslani et al., 2019). This study observed that the kaolin has the 
lowest direct shear strength. It was also noted that the inclusion of granular column increased the

447 shear strength of the geocomposite, regardless of the type of column backfill, due to the combined soil-granular column system, which has been observed by several researchers before (Mohapatra et al., 2016). For example, reinforcing the kaolin with the CWG column under the applied normal stresses of $12.5,25,50$ and $100 \mathrm{kPa}$ increased the shear strength from 5.7, 9.9, 15.7 and $33.2 \mathrm{kPa}$ to 8.9, 13.1, 29.9 and $49.3 \mathrm{kPa}$, respectively. As granular columns are formed by materials possessing relatively higher friction angle, the treated soil-column matrix manifest a higher friction angle than untreated soil, which is observed in the results presented in this study. Besides reinforcement, the increase in shear strength due to granular column inclusion could partly be due to the drainage ability of columns, causing a reduction in pore water pressure and an increase in effective stress of the soil (Najjar et al., 2010).

The obtained shear strength results reflect the overall response of the entire test specimens. The results showed that the increase in shear strength caused by the NS or MS column is comparable to each other, showing close peak friction angle values of $17.8^{\circ}$ and $17.7^{\circ}$ for the NS-kaolin and the MSkaolin geocomposite, respectively. The peak shear strength of the MS-kaolin geocomposite was higher than that of the NS-kaolin geocomposite. The potential reason for this finding could be the more wellgraded gradation of MS, favouring the development of higher peak shear stress (Siahaan et al., 2018). Another potential reason could be the relatively higher angularity of the MS particles Kazmi et al. (2021), leading to a superior interlock between the MS particles. Naeini and Gholampoor (2019) investigated the shear strength behaviour of stone column-treated wet clays by installing ordinary stone columns and geotextile-encased stone columns using three different sizes of stones, ranging 1$2 \mathrm{~mm}, 2-5 \mathrm{~mm}$ and 5-8 $\mathrm{mm}$. Their study found that the wet clay reinforced with columns containing coarser stones showed relatively greater shear strength than those containing smaller aggregates, potentially due to the higher friction angle of coarser stones. Similarly, Bareither et al. (2008) analysed the physical properties and shear strength of 30 compacted sands sourced from a wide range of geological deposits. Their study concluded that sands with the highest friction angle tend to have 
coarser particles, well-graded gradation and/or angular particle shape. Hence, previous studies support the results of this paper, as MS-kaolin geocomposite showed a higher shear strength than that of the NS-kaolin geocomposite.

Installing the CWG column caused a relatively higher increase in the peak shear strength of the geocomposite under higher normal stresses; this is reflected in the results of the CWG-kaolin geocomposite, showing the highest friction angle and the lowest cohesion among the three geocomposites. For example, the shear strength mobilised by the CWG-kaolin geocomposite under 50 and $100 \mathrm{kPa}$ normal stress were higher than that of the other two geocomposites. Secondly, installing the CWG column increased the friction angle from $14.0^{\circ}$ to $20.7^{\circ}$ ( $48 \%$ increase) compared to that of kaolin only. This notable increase in the friction angle caused by installing the CWG column suggests that the frictional resistance provided by the CWG column was an important factor contributing to the overall increase in the shear strength of the CWG-kaolin geocomposite. Technically, there is a significant difference in the Young's modulus of glass compared to that of traditional sands. Literature shows that the Young's Modulus of CWG is nearly 45 GPa (Hsieh et al., 2009; University of Texas, 2019), whereas that of sands and gravels varies from 10-170 Mpa (University of Texas, 2019). The potential reason for the highest increase in shear strength of the CWG-kaolin geocomposite could be the higher stiffness (Young's modulus) of CWG particles, causing relatively higher stress concentration on the CWG column, ultimately leading to more stress being taken by the CWG column than surrounding kaolin.

The post-shearing cross-section of the geocomposites under $25 \mathrm{kPa}$ applied normal stress are given in Figure 11. These cross-sectional photos were taken by splitting the geocomposites along their vertical axes to reveal the column and the surrounding kaolin. Upon careful examination of the geocomposites after shearing, it was noted that all three geocomposites underwent shear failure by lateral separation at the shearing plane. This finding complies with the previous literature, suggesting that a short column resting on a firm stratum typically fails in shear (Barksdale \& Bachus, 1983). Further, it was 
observed that the CWG-kaolin geocomposite showed some signs of column bulging, largely at the centre. This finding supports the hypothesis that the CWG column attracted relatively higher stress concentration due to the mentioned higher stiffness of CWG particles, causing the CWG column to mobilise greater passive resistance from surrounding kaolin than the NS or MS column.

The use of encasement with granular columns is a fairly common technique to improve their performance, particularly in soft soils. Typically, geosynthetic materials (geotextiles and geogrids) are suited for use as encasements due to their superior tensile characteristics. Geosynthetic encasement could also improve the lateral load capacity of the granular column by developing hoop tension forces in the encasement layer, giving additional confinement to the column material (Mohapatra et al., 2016). As a result, they minimise the chances for bulging failure and for penetration of column material into the surrounding soil that could inhibit the drainage ability of the column (Dutta et al., 2016). As this study is among the first to investigate the performance of a granular column based on its type of column backfilling material (NS, MS or CWG), it was logical not to encase the granular column during the tests, providing benchmark results excluding the effect of the encasement. Previous studies also show that ordinary granular columns are prone to shear rupture under lateral soil movement and ideally need some encasement to reduce the chances of rupturing under shear loading (Murugesan \& Rajagopal, 2009). Hence, future studies could consider investigating the direct shear behaviour of similar geocomposites with an encased column, particularly for granular columns made up of CWG. The next stage of this research will present results showing the effect of particle size of CWG on the geotechnical behaviour of kaolin reinforced with a CWG column.

\section{Conclusion}

518 This study investigated the shear strength behaviour of column-kaolin geocomposites containing a column made up of NS, MS or CWG installed in the middle of the kaolin bed. Overall, installing a granular column increased the shear strength of the geocomposite, regardless of the type of column backfill used. It was observed that the increase in shear strength along the horizontal plane at the mid- 
relatively comparable to each other, with the MS-kaolin geocomposite showing shear strength higher than that of the NS-kaolin geocomposite under all the applied normal stresses. A potential reason for this finding could be the well-graded gradation, higher particle angularity and larger median particle size of the MS than the NS. The results also showed that the CWG column is relatively more effective at increasing the peak shear strength of the geocomposite under higher normal stresses. It was noted that installing the CWG column led to the highest increase in the friction angle of the geocomposite. This could potentially be due to the higher stiffness of the CWG particles than that of the NS and the MS particles, causing greater stress concentration on the CWG column, ultimately leading to more stress being taken by the CWG column than the surrounding kaolin. Given the favourable performance demonstrated by the CWG column in this study, it is recommended to compare the experimental results of this study with field performance and large-scale physical model tests containing NS, MS or CWG columns. Secondly, this study suggests investigating the geotechnical behaviour of kaolin reinforced with groups of CWG columns. Given that this study is among the first to study the shear strength behaviour of CWG columns in clayey soil, it is also suggested for future researchers to study how CWG columns behave when encased with a suitable geosynthetic material. This study supports performing a detailed quantitative economic and environmental feasibility investigation for using CWG as column backfill in granular columns for future studies.

\section{Data Availability Statement}

541 All data, model, and code that support the findings of this study are available from the corresponding author upon reasonable request.

\section{Acknowledgment}

544 The authors would like to thank The University of Queensland (Australia) for providing the resources to perform this study. We are also thankful to Mr Peter Lovegrove (Enviro Sand, Australia) for supplying crushed waste glass for this study. Special thanks go to Professor Alexander Scheuermann (School of Civil Engineering at The University of Queensland), Dr Zhongwei Chen (School of Mechanical and Mining Engineering at The University of Queensland) and Dr Denys Villa Gomez (School of Civil 
549 Engineering at The University of Queensland) for providing their constructive suggestions. Gratitude

550 also goes to Dr Shideh Dashti (Department of Civil, Environmental and Architectural Engineering,

551 University of Colorado Boulder, USA) for providing her helpful suggestions.

\section{Notation}

553 The following symbols are used in this paper:

$554 \quad$ LDS Large direct shear test

555 NS Natural sand

556 MS Manufactured sand

$557 \quad$ CWG Crushed waste glass

$558 \quad$ LDSM $\quad$ Large direct shear test machine

$559 \quad$ LVDT Linear variable differential transducers

$560 \quad S_{u} \quad$ Undrained shear strength

$561 C_{r} \quad$ Column penetration ratio

562 PVC Polyvinyl Chloride

$563 \quad A_{r} \quad$ Area replacement ratio

564 L/D ratio Length to Diameter ratio

565 NSE Nash-Sutcliffe model efficiency coefficient

566 References

567 Abhishek, Rajyalakshmi, \& Madhav. (2016). Engineering of ground with granular piles: a critical 568 review. International Journal of Geotechnical Engineering, 10(4), 337-357.

569 Afshar, \& Ghazavi. (2014). A simple analytical method for calculation of bearing capacity of stone$570 \quad$ column. International Journal of Civil Engineering, 12(1), 15-25.

571 Afshar, Hemmati, \& Azimi. (2010). Laboratory Investigation on the Effect of Sand Columns on the 572 Shear Strength of Soft Soil Geo-Chicago 2016 (pp. 807-815).

573 Alfaro, Balasubramaniam, Bergado, \& Chai. (1994). Improvement techniques of soft ground in subsiding and lowland environment: CRC Press. 
Ali. (2012). Geotechnical characteristics of recycled glass in road pavement applications. Doktora Tezi, Swinburne University of Technology, Melbourne, Australia.

Alnunu, \& Nalbantoglu. (2019). Performance of loose sand with different waste materials in stone columns in North Cyprus. Environmental Geotechnics, 1-6.

Amini. (2016). Physical modelling of vibro stone column using recycled aggregates. University of Birmingham.

Andreou, Frikha, Frank, Canou, Papadopoulos, \& Dupla. (2008). Experimental study on sand and gravel columns in clay. Proceedings of the Institution of Civil Engineers-Ground Improvement,

Babu, Nayak, \& Shivashankar. (2013). A critical review of construction, analysis and behaviour of stone columns. Geotechnical and Geological Engineering, 31(1), 1-22.

Bareither, Edil, Benson, \& Mickelson. (2008). Geological and physical factors affecting the friction angle of compacted sands. Journal of Geotechnical and Geoenvironmental Engineering, 134(10), 1476-1489.

Barksdale, \& Bachus. (1983). Design and construction of stone columns, vol. I. Retrieved from Barmade, Kale, \& Gadekar. (2021). Experimental Study on Load-Settlement Behaviour of Granular Stone Column in Expansive Soil. Paper presented at the Proceedings of the Indian Geotechnical Conference 2019.

Bendixen, Best, Hackney, \& Iversen. (2019). Time is running out for sand: Nature Publishing Group. Bergado, Singh, Sim, Panichayatum, Sampaco, \& Balasubramaniam. (1990). Improvement of soft Bangkok clay using vertical geotextile band drains compared with granular piles. Geotextiles and Geomembranes, 9(3), 203-231. 
601

602

603

604

605

606

607

608

609

610

611

612

613

614

615

616

617

618

619

620

621

622

623

624

625

Bravo, De Brito, Pontes, \& Evangelista. (2015). Mechanical performance of concrete made with aggregates from construction and demolition waste recycling plants. Journal of Cleaner Production, 99, 59-74.

Canakci, Celik, \& Edil. (2017). Effect of sand column on compressibility and shear strength properties of peat. European Journal of Environmental and Civil Engineering, 1-12.

Castro. (2017). Modeling stone columns. Materials, 10(7), 782.

Chawla, Raju, \& Krishna. (2010). Some environmental benefits of dry vibro stone columns in a gas based power plant project. Paper presented at the Indian Geotechnical Conference. Mumbai, India: gndec. ac. in.

Chiew, \& McMahon. (1993). Assessing the adequacy of catchment streamflow yield estimates. Soil Research, 31(5), 665-680.

Clean Washington Center. (1996). Best Practices in Glass Recycling - Analysis of Glass Dusts. Retrieved from http://citeseerx.ist.psu.edu/viewdoc/download;jsessionid=8EA266C3CB54A9A2141B63AAB2 EDBA2C?doi=10.1.1.384.5175\&rep=rep1\&type=pdf

Dash, \& Bora. (2013). Influence of geosynthetic encasement on the performance of stone columns floating in soft clay. Canadian Geotechnical Journal, 50(7), 754-765.

Dutta, Nadaf, Lal Birali, \& Mandal. (2016). Encased stone columns for soft ground improvement GeoChicago 2016 (pp. 746-755).

Egan, \& Slocombe. (2010). Demonstrating environmental benefits of ground improvement. Proceedings of the Institution of Civil Engineers-Ground Improvement, 163(1), 63-69.

Gourley, Newill, \& Schreiner. (1993). Expansive soils: TRL's research strategy. Paper presented at the Proc., 1st Int. Symp. on Engineering Characteristics of Arid Soils.

Hanna, Etezad, \& Ayadat. (2013). Mode of failure of a group of stone columns in soft soil. International Journal of Geomechanics, 13(1), 87-96. 
Holmstrom, \& Swan. (1999). Geotechnical properties of innovative, synthetic lightweight aggregates. Paper presented at the Proceedings of the 1999 International Ash Utilization Symposium, Lexington, $\mathrm{KY}$.

Hsieh, Lin, Su, \& Jang. (2009). Glass forming ability and mechanical properties characterization on Mg58Cu31Y11- xGdx bulk metallic glasses. Journal of alloys and compounds, 483(1-2), 4043.

Kazmi, Serati, Williams, Qasim, \& Cheng. (2020a). The potential use of crushed waste glass as a sustainable alternative to natural and manufactured sand in geotechnical applications. Journal of Cleaner Production, 124762.

Kazmi, Serati, Williams, Qasim, \& Cheng. (2021). The potential use of crushed waste glass as a sustainable alternative to natural and manufactured sand in geotechnical applications. Journal of Cleaner Production, 284, 124762.

Kazmi, Serati, Williams, Qasim, Cheng, \& Olaya. (2020b). A Comparative Study on Shear Strength of Crushed Waste Glass with Natural and Manufactured Sand. Paper presented at the 54th US Rock Mechanics/Geomechanics Symposium.

Kazmi, Serati, Williams, Qasim, Cheng, \& Olaya. (2020c). A Comparative Study on Shear Strength of Crushed Waste Glass with Natural and Manufactured Sand. Paper presented at the 54th US Rock Mechanics/Geomechanics Symposium.

Kazmi, Williams, \& Serati. (2019a). Comparison of Basic Geotechnical Parameters of Crushed Waste Glass with Natural and Manufactured Sands. Paper presented at the 53rd US Rock Mechanics/Geomechanics Symposium.

Kazmi, Williams, \& Serati. (2019b). Waste Glass in Civil Engineering Applications-A Review. International Journal of Applied Ceramic Technology.

Kumar, \& Sadana. (2012). Bearing capacity of soil reinforced with vertical columns of recycled concrete aggregates. Australian Journal of Civil Engineering, 10(2), 153-162. 
651

652

653

654

655

656

657

658

659

660

661

662

663

664

665

666

667

668

669

670

671

672

673

674

675

676

Langer, Drew, \& Sachs. (2004). Aggregate and the environment: American Geological Institute Environmental Awareness, Series No. 8. American Geological Institute, Alexandria, VA.

Malarvizhi. (2007). Comparative study on the behavior of encased stone column and conventional stone column. Soils and Foundations, 47(5), 873-885.

Manohar, \& Patel. (2021). Ground Improvement with Stone Columns-A Review Advances in Civil Engineering (pp. 197-217): Springer.

McCabe, McNeill, \& Black. (2007). Ground improvement using the vibro-stone column technique.

Mehrannia, Kalantary, \& Ganjian. (2018). Experimental study on soil improvement with stone columns and granular blankets. Journal of Central South University, 25(4), 866-878.

Mishra, Bore, Jiang, Scheuermann, \& Li. (2018a). Dielectric spectroscopy measurements on kaolin suspensions for sediment concentration monitoring. Measurement, 121, 160-169.

Mishra, Scheuermann, \& Li. (2018b). Significance of corrections and impact of saline pore fluid on kaolin. Journal of Materials in Civil Engineering, 30(11), 06018016.

Mishra, Zhang, Bhuyan, \& Scheuermann. (2020). Anisotropy in volume change behaviour of soils during shrinkage. Acta Geotechnica, 15(12), 3399-3414.

Mitchell. (1970). In-place treatment of foundation soils. Journal of Soil Mechanics \& Foundations Div, 97(SM1).

Mohapatra, Rajagopal, \& Sharma. (2014). Analysis of geotextile-reinforced stone columns subjected to lateral loading. Paper presented at the Proc. 10th Int. Conf. on Geosynthetics, Berlin, Germany.

Mohapatra, Rajagopal, \& Sharma. (2016). Direct shear tests on geosynthetic-encased granular columns. Geotextiles and Geomembranes, 44(3), 396-405.

Mokhtari, \& Kalantari. (2012). Soft Soil Stabilization using Stone Column--A Review. Electronic journal of Geotechnical engineering, 17, 1459-1466.

Murugesan, \& Rajagopal. (2007). Model tests on geosynthetic-encased stone columns. Geosynthetics International, 14(6), 346-354. 
Murugesan, \& Rajagopal. (2009). Shear load tests on stone columns with and without geosynthetic encasement. Geotechnical Testing Journal, 32(1), 76-85.

Naeini, \& Gholampoor. (2019). Effect of Geotextile Encasement on the Shear Strength Behavior of Stone Column-Treated Wet Clays. Indian Geotechnical Journal, 49(3), 292-303.

Najjar. (2013). A state-of-the-art review of stone/sand-column reinforced clay systems. Geotechnical and Geological Engineering, 31(2), 355-386.

Najjar, Sadek, \& Maakaroun. (2010). Effect of sand columns on the undrained load response of soft clays. Journal of Geotechnical and Geoenvironmental Engineering, 136(9), 1263-1277.

$\mathrm{Ng}$, \& Tan. (2015). Stress transfer mechanism in 2D and 3D unit cell models for stone column improved ground. International Journal of Geosynthetics and Ground Engineering, 1(1), 3.

Poorooshasb, \& Meyerhof. (1997). Analysis of behavior of stone columns and lime columns. Computers and Geotechnics, 20(1), 47-70.

Priebe. (1995). The design of vibro replacement. Ground engineering, 28(10), 31.

Ranjan. (1989). Ground treated with granular piles and its response under load. Indian Geotechnical Journal, 19(1), 1-86.

Rossato, Ninis, \& Jardine. (1992). Properties of some kaolin-based model clay soils. Geotechnical Testing Journal, 15(2), 166-179.

Saberian, Li, \& Cameron. (2019). Effect of crushed glass on behavior of crushed recycled pavement materials together with crumb rubber for making a clean green base and subbase. Journal of Materials in Civil Engineering, 31(7), 04019108.

Serridge. (2004). THE USE OF RECYCLED AGGREGATES IN VIBRO STONE COLUMN GROUND IMPROVEMENT TECHNIQUES Sustainable Waste Management and Recycling: Construction Demolition Waste (pp. 213-224): Thomas Telford Publishing.

Serridge, \& Sarsby. (2009). Assessment of the use of recycled aggregates in vibro-stone column ground improvement techniques Construction for a Sustainable Environment (pp. 86-101): CRC Press. 
Serridge, \& Slocombe. (2012). Chapter 84 Ground improvement ICE manual of geotechnical engineering (pp. 1247-1269): Thomas Telford Ltd.

Shahverdi, \& Haddad. (2020). Use of recycled materials in floating stone columns. Proceedings of the Institution of Civil Engineers-Construction Materials, 173(2), 99-108.

Siahaan, Indraratna, Ngo, Rujikiatkamjorn, \& Heitor. (2018). Influence of Particle Gradation and Shape on the Performance of Stone Columns in Soft Clay. Geotechnical Testing Journal, 41(6), 1076-1091.

Sivakumar, O'Kelly, Moorhead, Madhav, \& Mackinnon. (2014). Effectiveness of granular columns in containing settlement. Proceedings of the Institution of Civil Engineers-Geotechnical Engineering, 167(4), 371-379.

Spoor, \& Godwin. (1979). Soil deformation and shear strength characteristics of some clay soils at different moisture contents. Journal of Soil Science, 30(3), 483-498.

University of Texas. (2019). Some Useful Numbers on the Engineering Properties of Materials (Geologic and Otherwise) GEOL 615. Retrieved from $\underline{\text { https://www.jsg.utexas.edu/tyzhu/files/Some-Useful-Numbers.pdf }}$

Wang. (2009). Consolidation of soft clay foundations reinforced by stone columns under timedependent loadings. Journal of Geotechnical and Geoenvironmental Engineering, 135(12), $1922-1931$.

Wroth, \& Wood. (1978). The correlation of index properties with some basic engineering properties of soils. Canadian Geotechnical Journal, 15(2), 137-145.

Xu, Methiwala, Williams, \& Serati. (2018). Strength and consolidation characteristics of clay with geotextile-encased sand column. Proceedings of the Institution of Civil Engineers-Ground Improvement, 171(3), 125-134.

Zukri, \& Nazir. (2018). Sustainable materials used as stone column filler: A short review. MS\&E, 342(1), 012001. 
730 Table 1. Results of mineralogical analysis performed using XRF spectroscopy (Kazmi et al., 2021).

\begin{tabular}{|c|c|c|c|c|}
\hline Oxide concentration & Units & Natural sand & Manufactured sand & $\begin{array}{c}\text { Crushed } \\
\text { waste glass }\end{array}$ \\
\hline $\mathrm{SiO}_{2}$ & $\%$ & 99.81 & 67.74 & 72.07 \\
\hline $\mathrm{TiO}_{2}$ & $\%$ & 0.06 & 0.67 & 0.05 \\
\hline $\mathrm{Al}_{2} \mathrm{O}_{3}$ & $\%$ & $<0.01$ & 16.17 & 1.45 \\
\hline $\mathrm{Fe}_{2} \mathrm{O}_{3}$ & $\%$ & 0.05 & 5.81 & 0.34 \\
\hline $\mathrm{MnO}$ & $\%$ & $<0.01$ & 0.12 & 0.01 \\
\hline $\mathrm{MgO}$ & $\%$ & 0.03 & 2.13 & 0.69 \\
\hline $\mathrm{CaO}$ & $\%$ & 0.01 & 1.38 & 11.09 \\
\hline $\mathrm{Na}_{2} \mathrm{O}$ & $\%$ & $<0.01$ & 1.71 & 13.73 \\
\hline $\mathrm{K}_{2} \mathrm{O}$ & $\%$ & 0.01 & 3.72 & 0.33 \\
\hline $\mathrm{P}_{2} \mathrm{O}_{5}$ & $\%$ & 91.07 & 0.16 & 0.03 \\
\hline $\mathrm{SO}_{3}$ & $\%$ & 82.43 & 0.24 & 0.09 \\
\hline $\mathrm{V}_{2} \mathrm{O}_{5}$ & $\mathrm{ppm}$ & 9 & 177 & 20 \\
\hline $\mathrm{Cr}_{2} \mathrm{O}_{3}$ & ppm & 11 & 97 & 539 \\
\hline $\mathrm{ZnO}$ & ppm & 5 & 122 & 72 \\
\hline $\mathrm{SrO}$ & ppm & 2 & 133 & 155 \\
\hline $\mathrm{BaO}$ & $\mathrm{ppm}$ & 26 & 920 & 355 \\
\hline $\mathrm{CO}_{3} \mathrm{O}_{4}$ & ppm & 42 & 18 & 26 \\
\hline $\mathrm{NiO}$ & $\mathrm{ppm}$ & 8 & 42 & 4 \\
\hline $\mathrm{CuO}$ & $\mathrm{ppm}$ & $<2$ & 37 & 4 \\
\hline
\end{tabular}


Table 2. Geotechnical parameters of the materials (Adapted from Kazmi et al. (2021) and Xu et al.

\begin{tabular}{|c|c|c|c|c|c|}
\hline Parameter & NS & MS & CWG & Kaolin & Standards \\
\hline $\mathrm{C}_{\mathrm{u}}$ & 1.43 & 13.37 & 2.21 & - & - \\
\hline $\mathrm{C}_{\mathrm{c}}$ & 0.94 & 1.51 & 0.96 & - & - \\
\hline $\begin{array}{c}\text { Minimum dry } \\
\text { density (dry } \\
\text { placement method) } \\
\left(\mathrm{kg} / \mathrm{m}^{3}\right)\end{array}$ & 1540 & 1690 & 1390 & - & AS 1289.5.5.1-1998 \\
\hline $\begin{array}{c}\text { Maximum dry } \\
\text { density (Wet } \\
\text { placement method) } \\
\left(\mathrm{kg} / \mathrm{m}^{3}\right)\end{array}$ & 1650 & 1960 & 1820 & - & AS 1289.5.5.1-1998 \\
\hline $\begin{array}{c}\text { Hydraulic } \\
\text { conductivity } \\
(\mathrm{m} / \mathrm{s})\end{array}$ & $3.81 \times 10^{-4}$ & $3.59 \times 10-4$ & $4.01 \times 10-4$ & - & ASTM D2434-68 \\
\hline $\begin{array}{c}\text { Abrasion loss } \\
(\%)\end{array}$ & 6.00 & 9.60 & 2.40 & - & ASTM D7428 \\
\hline $\begin{array}{c}\text { Critical-state friction } \\
\text { angle under dry } \\
\text { conditions } \\
\left({ }^{\circ}\right)\end{array}$ & 31.1 & 44.1 & 29.1 & - & AS 1289.6.2.2-1998 \\
\hline $\begin{array}{l}\text { Critical-state friction } \\
\text { angle under } \\
\text { saturated conditions } \\
\left({ }^{\circ}\right)\end{array}$ & 30.7 & 41.3 & 32.4 & - & AS 1289.6.2.2-1998 \\
\hline $\begin{array}{c}\text { Particle roundness } \\
\text { index }\end{array}$ & $\begin{array}{c}0.55 \\
\text { (Rounded) }\end{array}$ & $\begin{array}{c}0.24 \\
\text { (Sub-angular) }\end{array}$ & $\begin{array}{c}0.32 \\
\text { (Sub-rounded) }\end{array}$ & - & - \\
\hline Specific gravity & 2.63 & 2.74 & 2.50 & 2.61 & ASTM D5550 \\
\hline $\begin{array}{l}\text { Median particle size } \\
(\mathrm{mm})\end{array}$ & 0.29 & 1.55 & 1.42 & 0.0012 & AS 1289.3.6.1-2009 \\
\hline $\begin{array}{l}\text { Liquid limit } \\
(\%)\end{array}$ & - & - & - & 90 & ASTM D4318 - 10 \\
\hline $\begin{array}{l}\text { Plastic limit } \\
(\%)\end{array}$ & - & - & - & 35 & ASTM D4318 - 10 \\
\hline $\begin{array}{l}\text { Plasticity index } \\
(\%)\end{array}$ & - & - & - & 55 & ASTM D4318 - 10 \\
\hline $\begin{array}{l}\mathrm{F}_{200} \\
(\%)\end{array}$ & - & - & - & 69 & \\
\hline $\begin{array}{c}\text { Unified soil } \\
\text { classification system } \\
\text { (USCS) rating }\end{array}$ & SP & SW & SP & $\mathrm{CH}$ & ASTM D2487 - 06 \\
\hline
\end{tabular}

Table 3. Comparison of the shear strength of kaolin with geocomposites

\begin{tabular}{|r|c|c|c|c|}
\cline { 2 - 4 } \multicolumn{1}{c|}{} & Kaolin & $\begin{array}{c}\text { NS-kaolin } \\
\text { geocomposite }\end{array}$ & $\begin{array}{c}\text { MS-kaolin } \\
\text { geocomposite }\end{array}$ & $\begin{array}{c}\text { CWG-kaolin } \\
\text { geocomposite }\end{array}$ \\
\hline Cohesion $(\mathrm{kPa})$ & 1.7 & 3.9 & 5.4 & 3.1 \\
\hline Angle of internal friction $\left(^{\circ}\right)$ & 14.0 & 17.8 & 17.7 & 20.7 \\
\hline
\end{tabular}


737 Fig.1. Installation of the granular column through dry bottom-feed technique (Adapted from (Serridge

738 \& Slocombe, 2012))

739 Fig.2. Optical microscopic images of NS, MS and CWG (from left to right)

740 Fig.3. Gradation curve of the test materials (Adapted from Kazmi et al. (2021) and Xu et al. (2018))

741 Fig.4. Large direct shear machine (Wille Geotechnik ADS-300)

742 Fig.5a. Typical plan of the geocomposite

743 Fig.5b. Typical cross-section of the geocomposite

744 Fig.6a. Experimental set up prepared in the shear box for kaolin specimen

745 Fig.6b. Experimental set up prepared in the shear box for NS-kaolin geocomposite

746 Fig.6c. Experimental set up prepared in the shear box for MS-kaolin geocomposite

747 Fig.6d. Experimental set up prepared in the shear box for CWG-kaolin geocomposite

$748 \quad$ Fig.7. Peak shear strength envelopes of kaolin and the geocomposites

749 Fig.8a. Shear stress-horizontal displacement behaviour of kaolin

750 Fig.8b. Shear stress-horizontal displacement behaviour of NS-kaolin geocomposite

751 Fig.8c. Shear stress-horizontal displacement behaviour of MS-kaolin geocomposite

752 Fig.8d. Shear stress-horizontal displacement behaviour of CWG-kaolin geocomposite

753 Fig.9a. Horizontal-vertical displacement behaviour of kaolin specimen

754 Fig.9b. Horizontal-vertical displacement behaviour of NS-kaolin geocomposite

755 Fig.9c. Horizontal-vertical displacement behaviour of MS-kaolin geocomposite

756 Fig.9d. Horizontal-vertical displacement behaviour of CWG-kaolin geocomposite

757 Fig.10. Maximum vertical displacement-normal stress behaviour of the specimens

758 Fig.11. Post-shearing cross-section of the geocomposites under $25 \mathrm{kPa}$ normal stress (NS-kaolin, MSkaolin and CWG-kaolin geocomposite from left to right) 

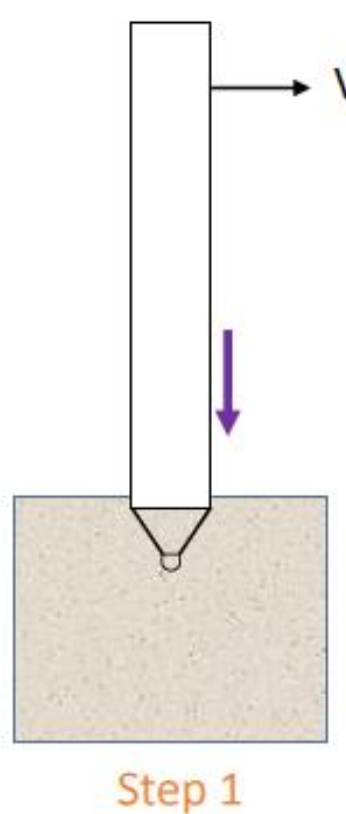

Penetration
Vibroflot

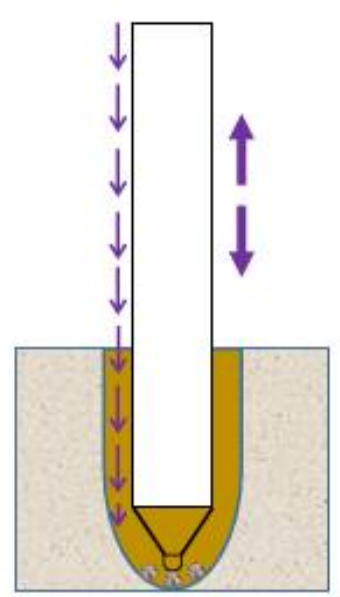

Step 2

Delivery

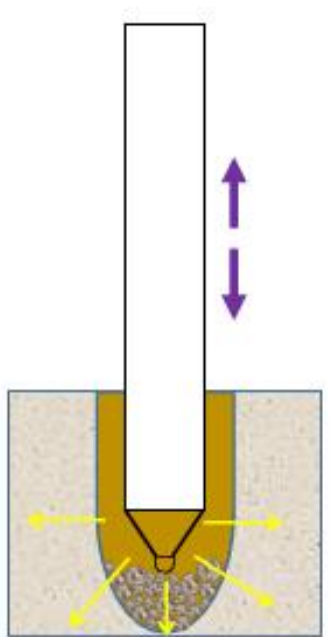

Step 3

Compaction

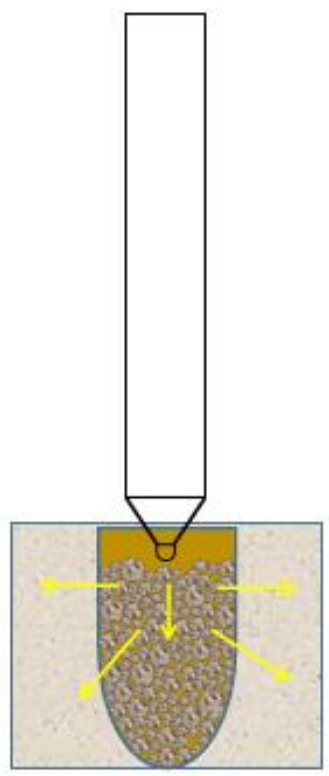

Step 4

Finishing

762

Fig.1. Installation of the granular column through dry bottom-feed technique (Adapted from
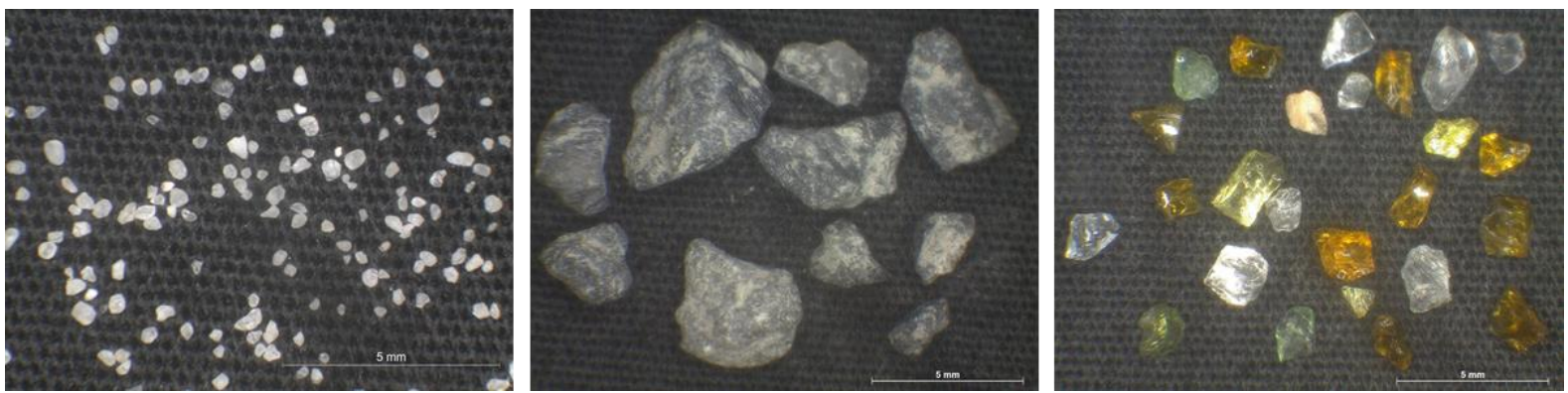

Fig.2. Optical microscopic images of NS, MS and CWG (from left to right) 


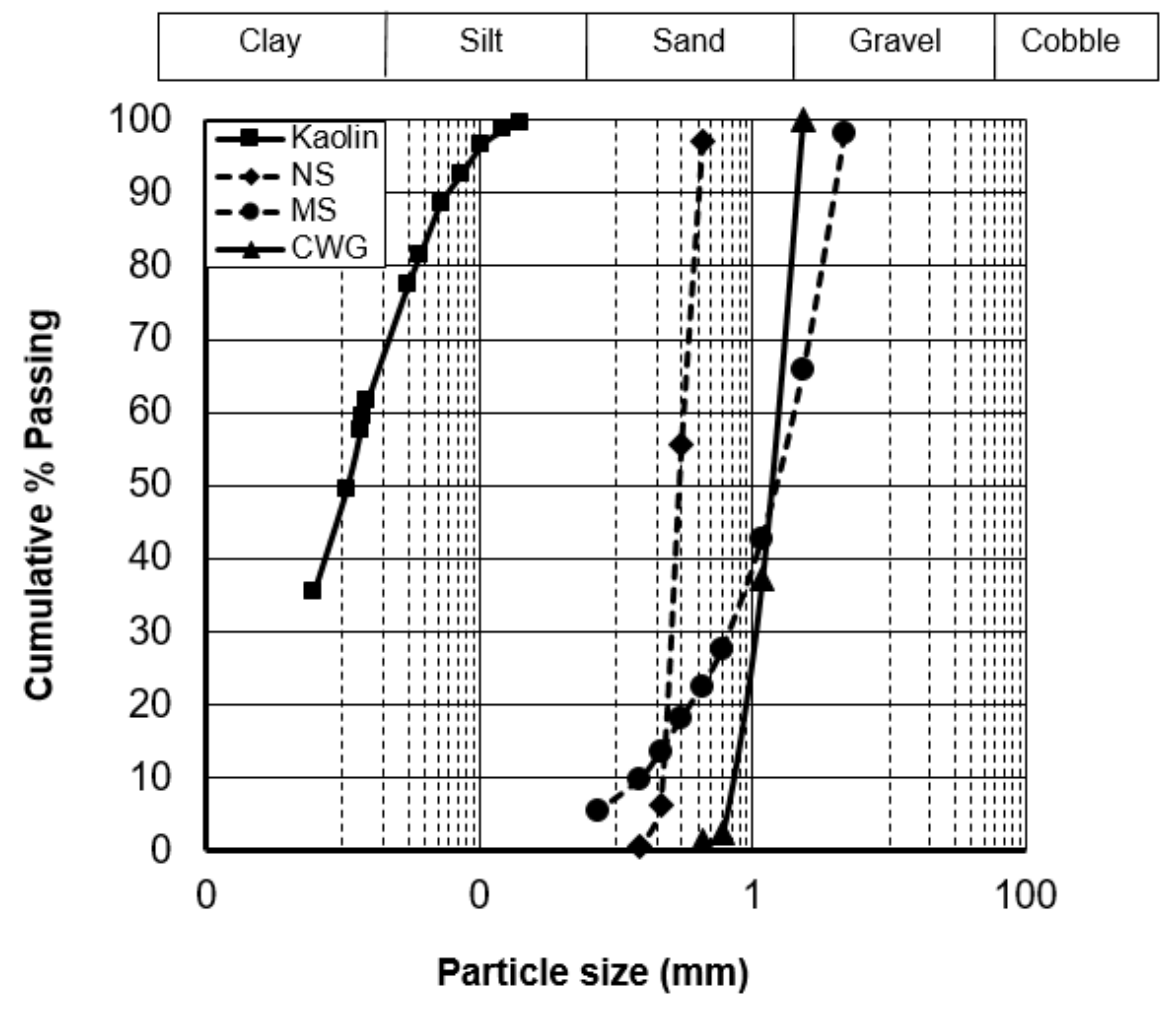

Fig.2. Gradation curve of the test materials (Adapted from Kazmi et al. (2021) and Xu et al. (2018))

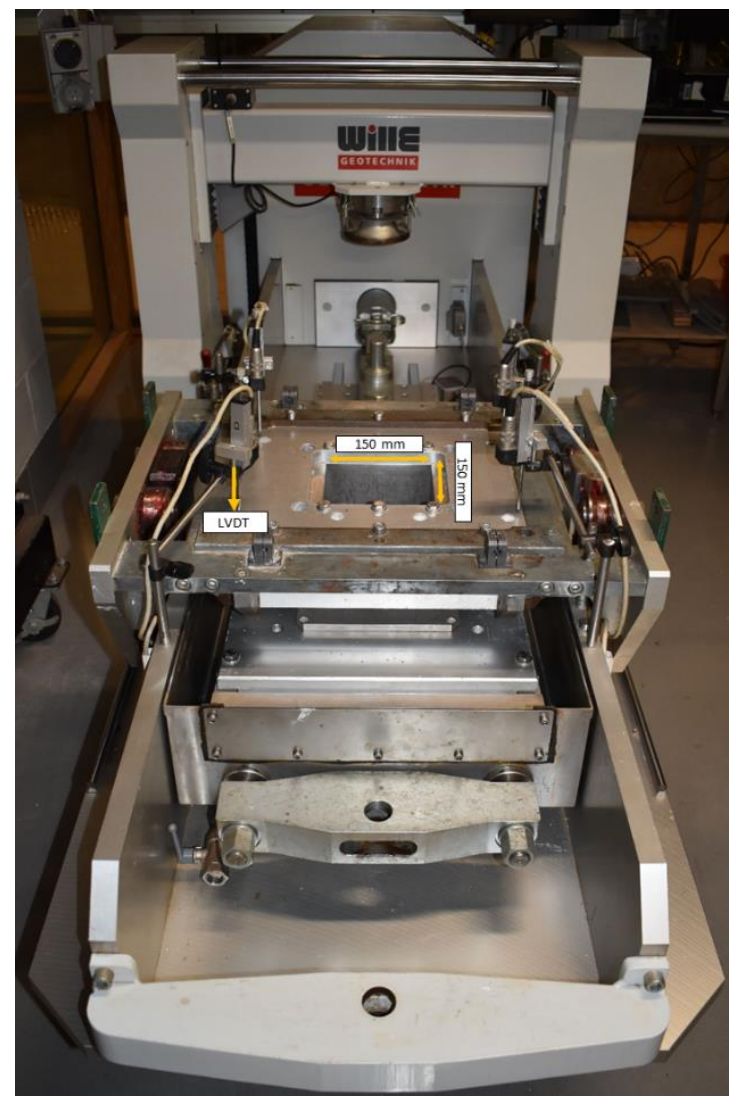

Fig.4. Large direct shear machine (Wille Geotechnik ADS-300) 


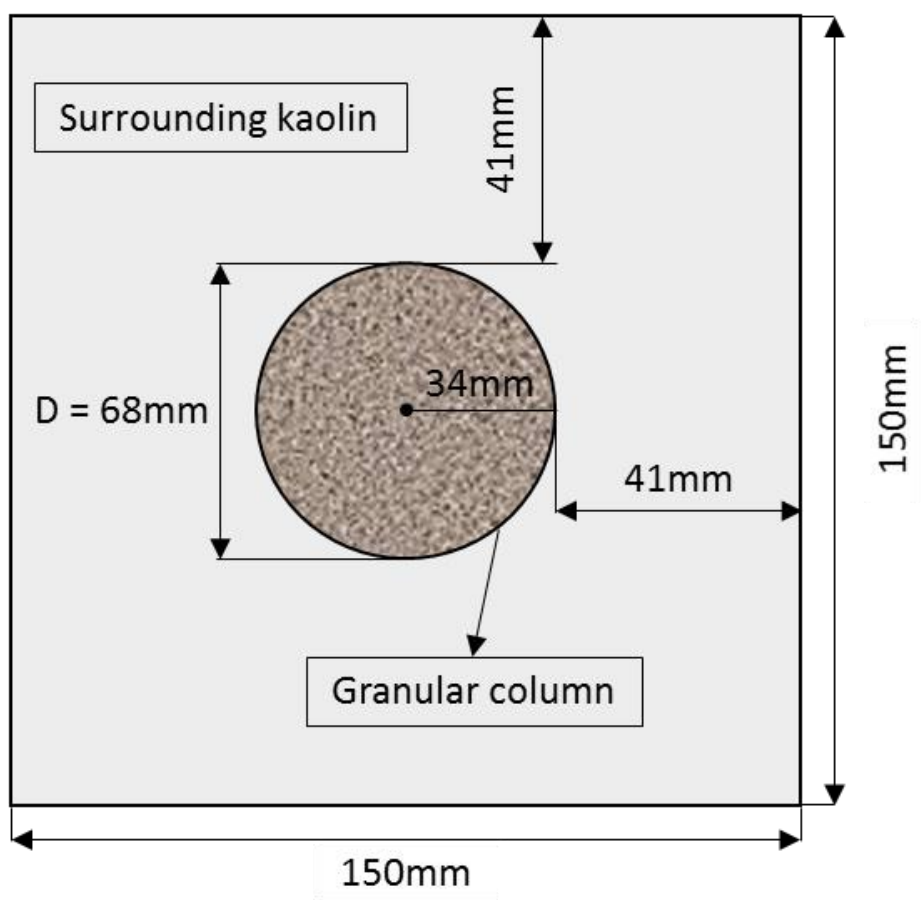

Fig.5a. Typical plan of the geocomposite

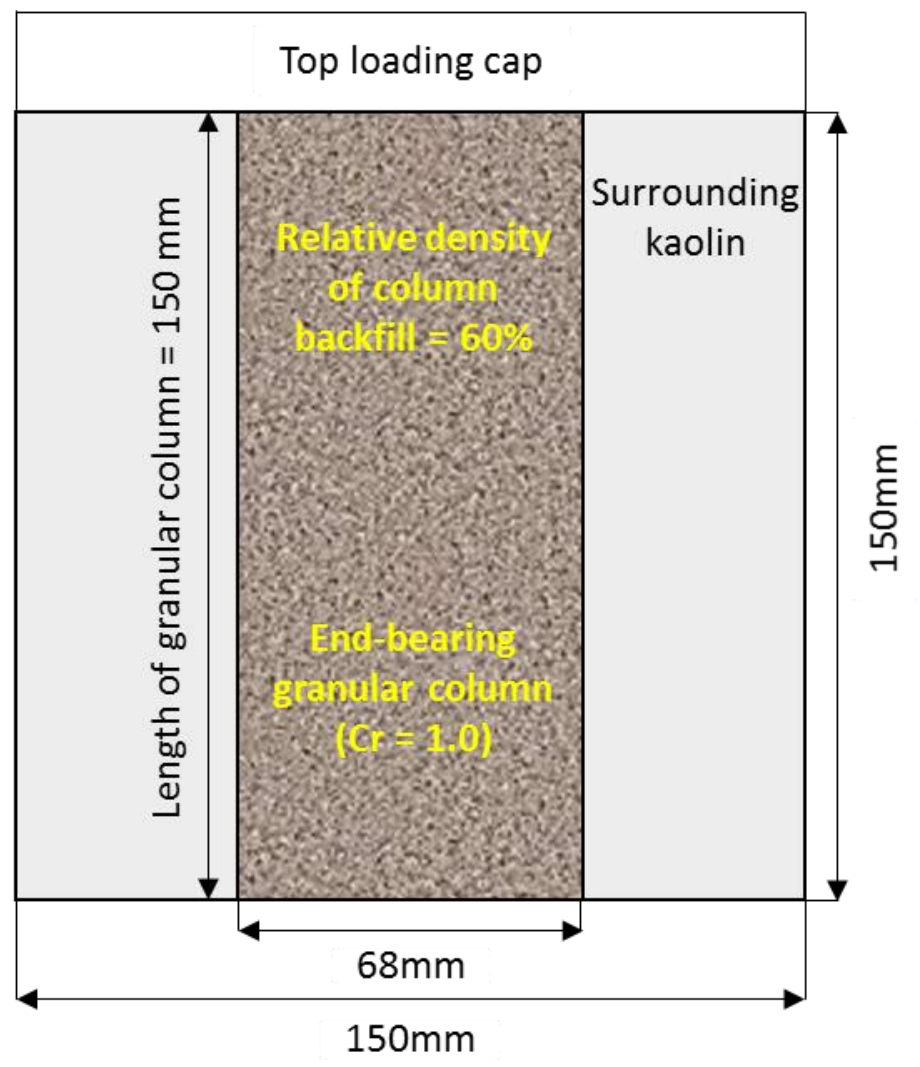

Fig.5b. Typical cross-section of the geocomposite 
Fig.6a. Pure kaolin sample prepared in the shear box

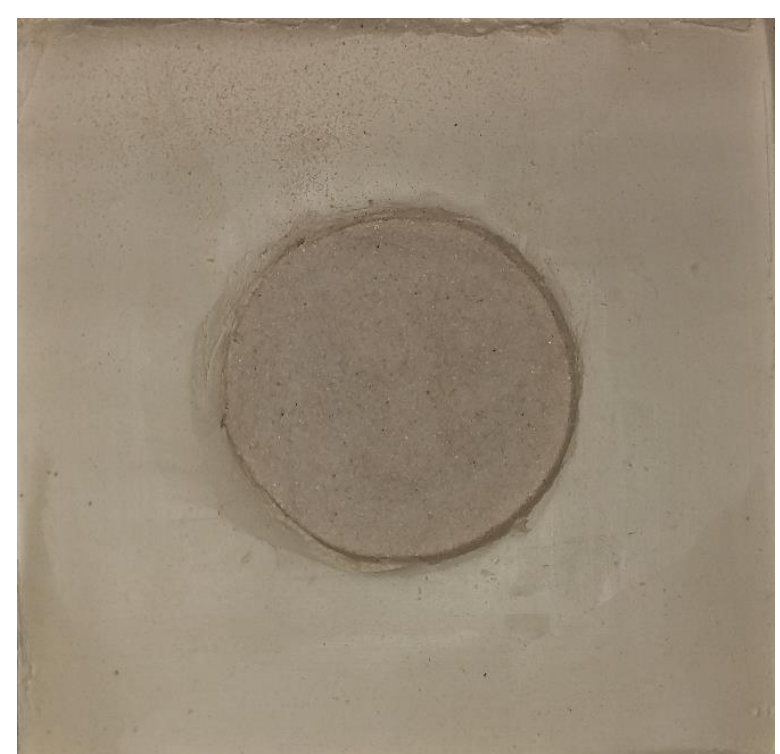

Fig.6b. NS-kaolin geocomposite prepared in the shear box

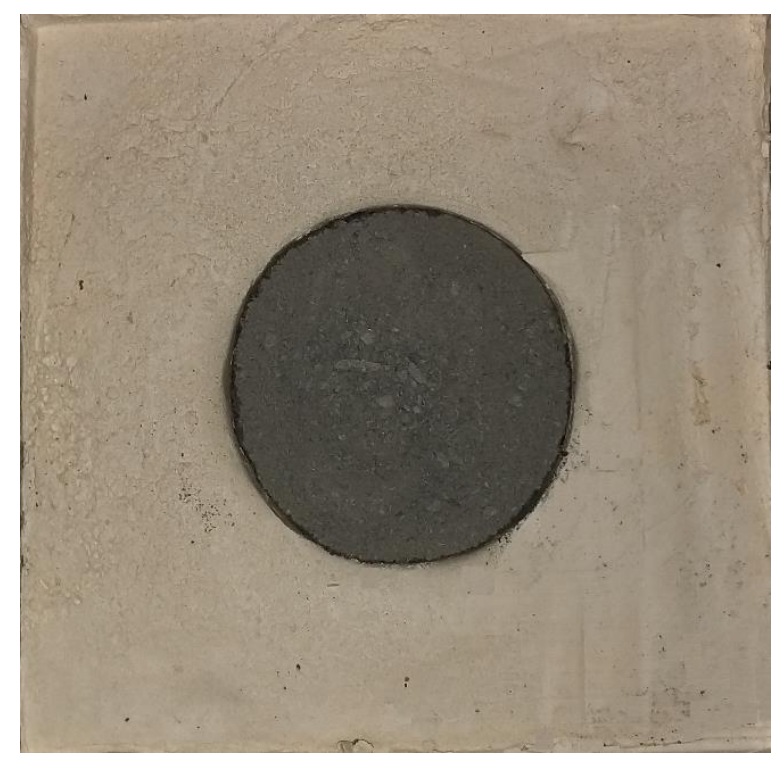

Fig.6c. MS-kaolin geocomposite prepared in the shear box 
852

853

854

855

856

857

858

859

860

861

862

863

864

865

Fig.6d. CWG-kaolin geocomposite prepared in the shear box 


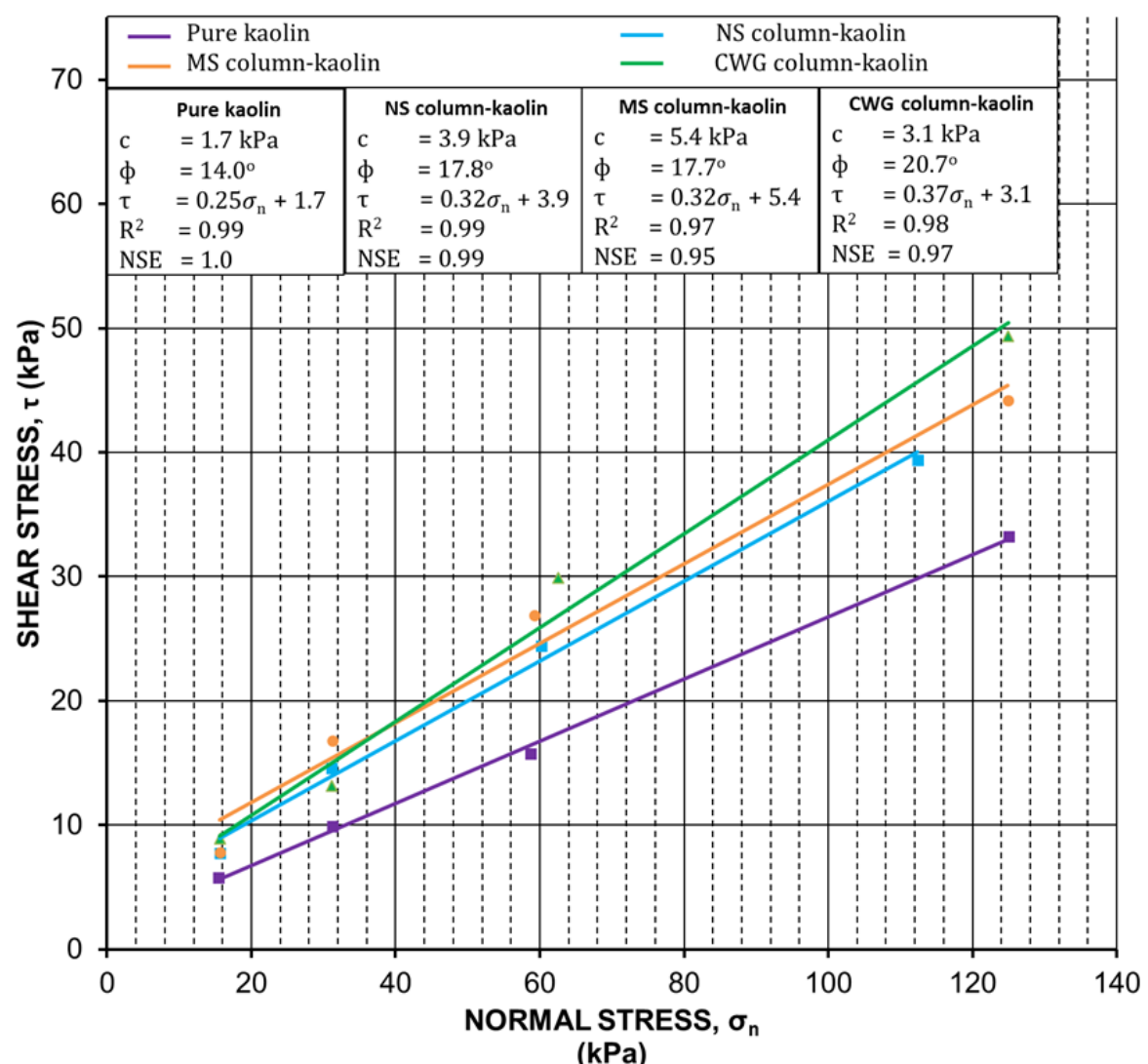

Fig.7. Peak shear strength envelopes of pure kaolin and the geocomposites 


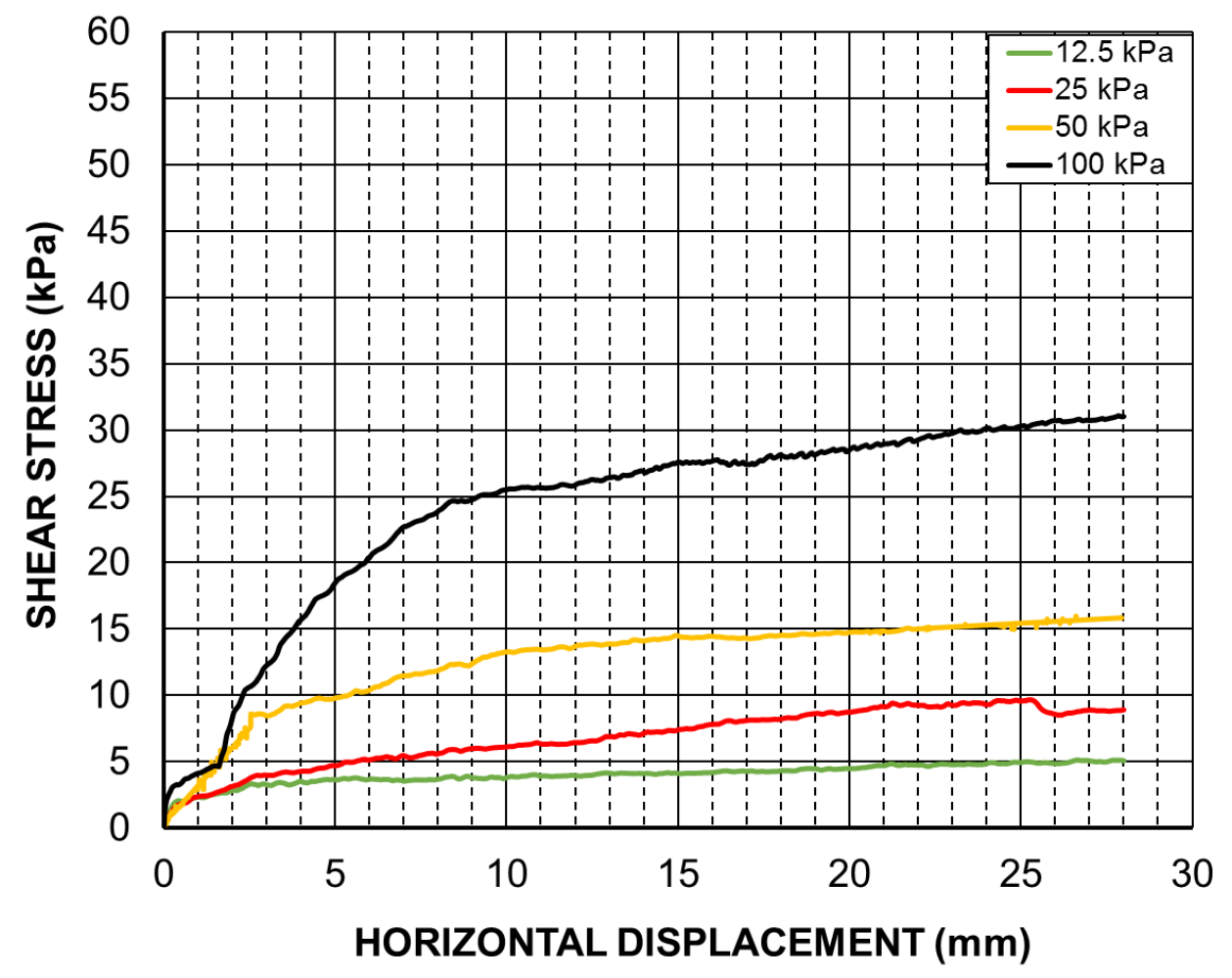

891

Fig.8a. Shear stress-horizontal displacement behaviour of pure kaolin sample

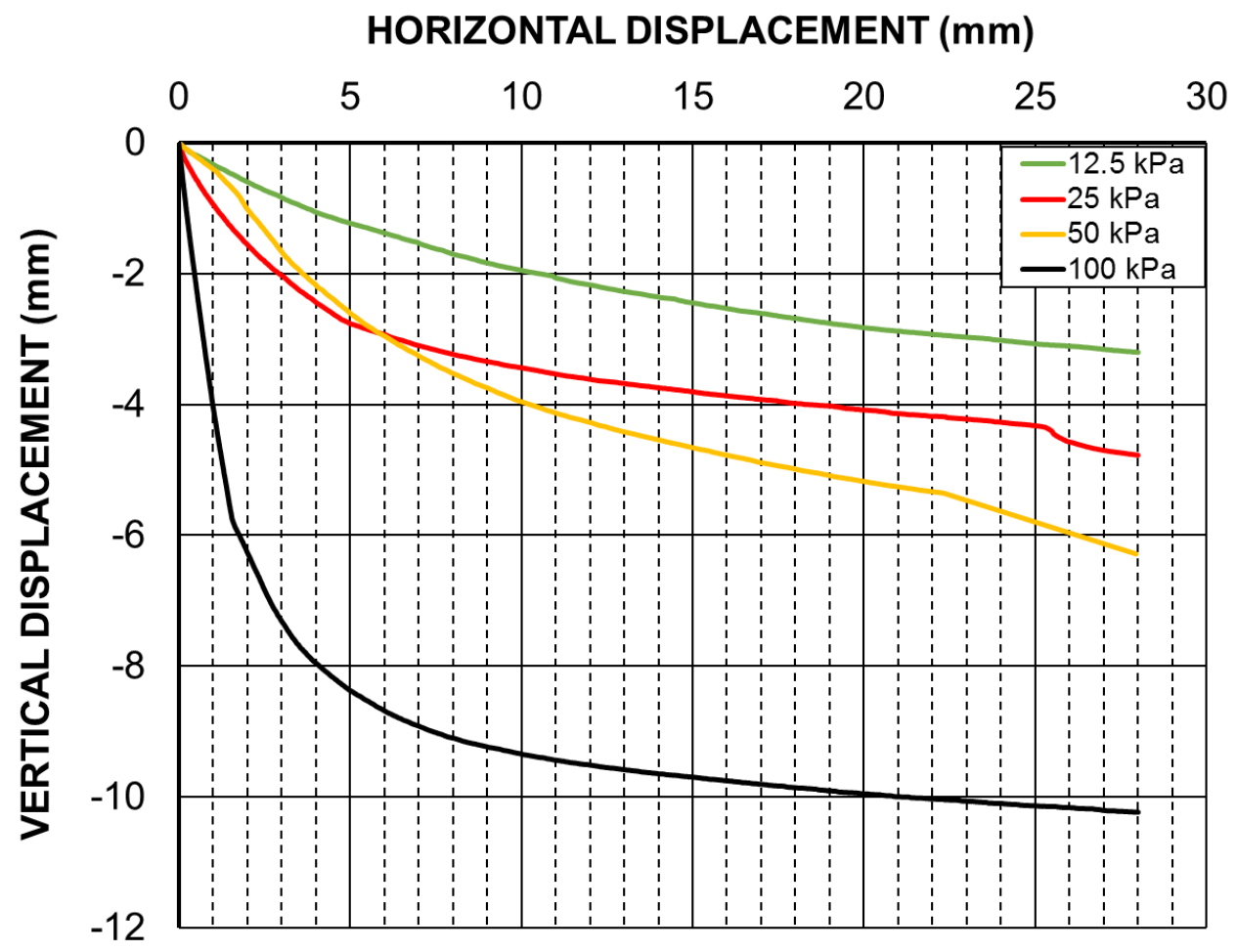

Fig.9a. Horizontal-vertical stress displacement behaviour of pure kaolin sample 


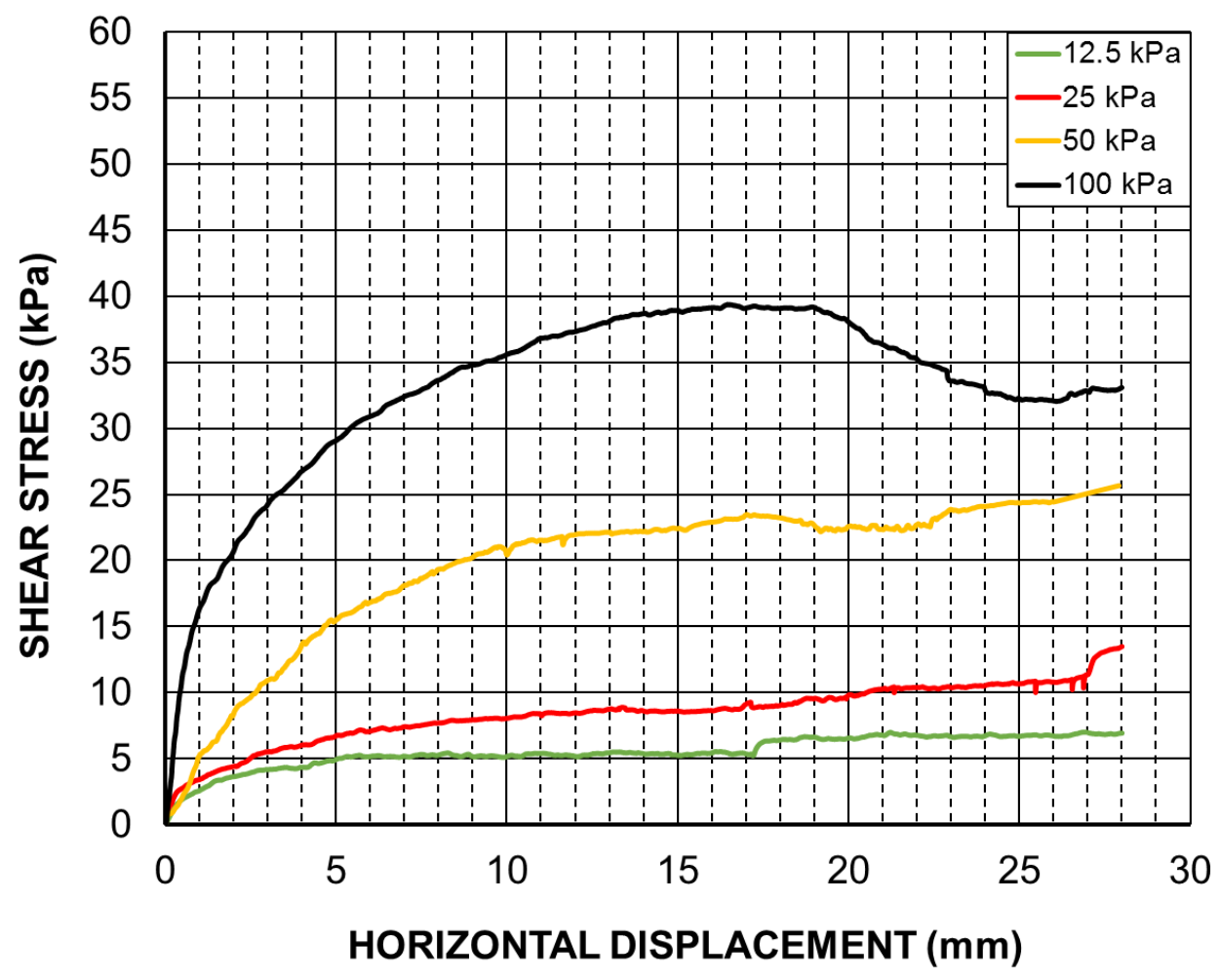

Fig.8b. Shear stress-horizontal displacement behaviour of NS-kaolin geocomposite HORIZONTAL DISPLACEMENT (mm)

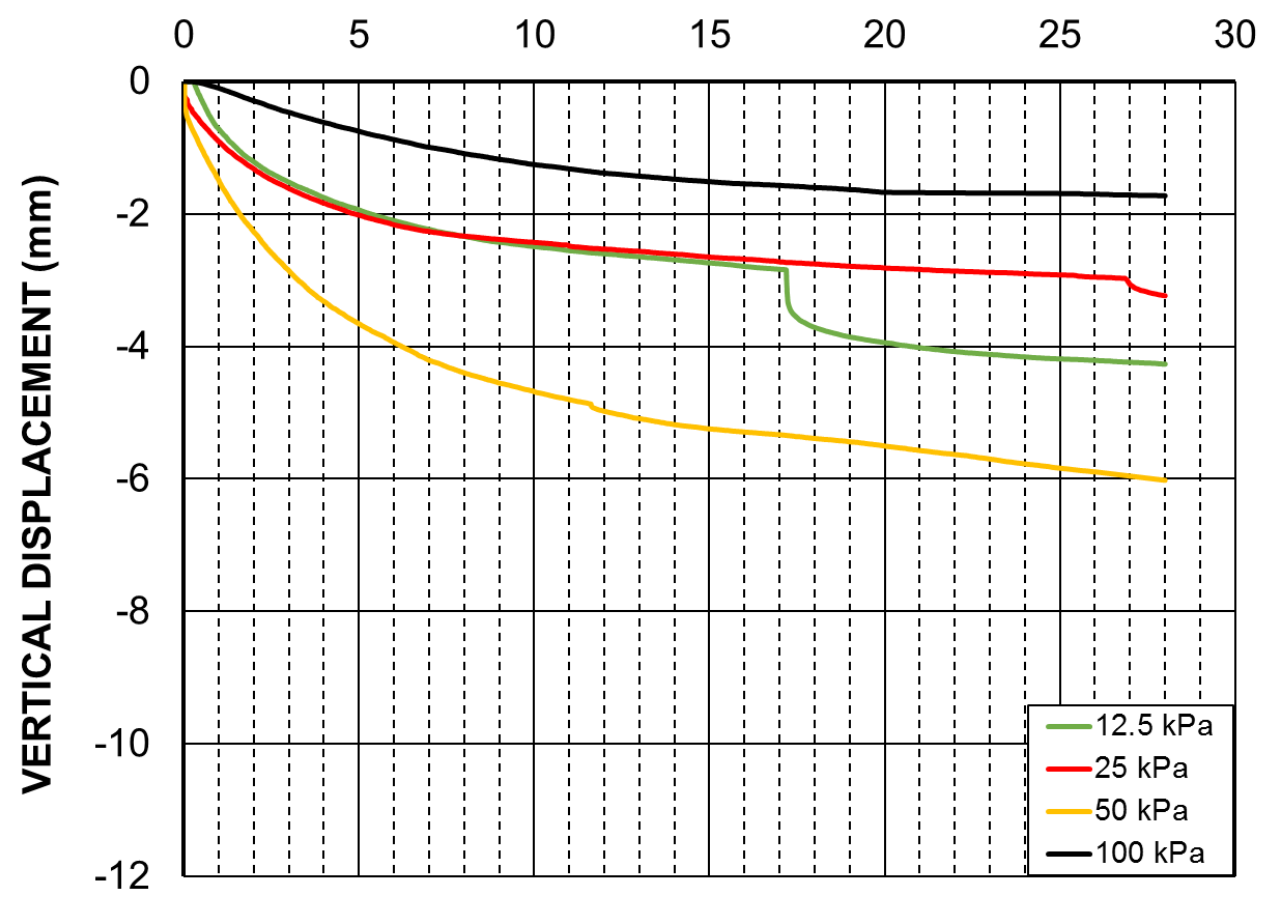




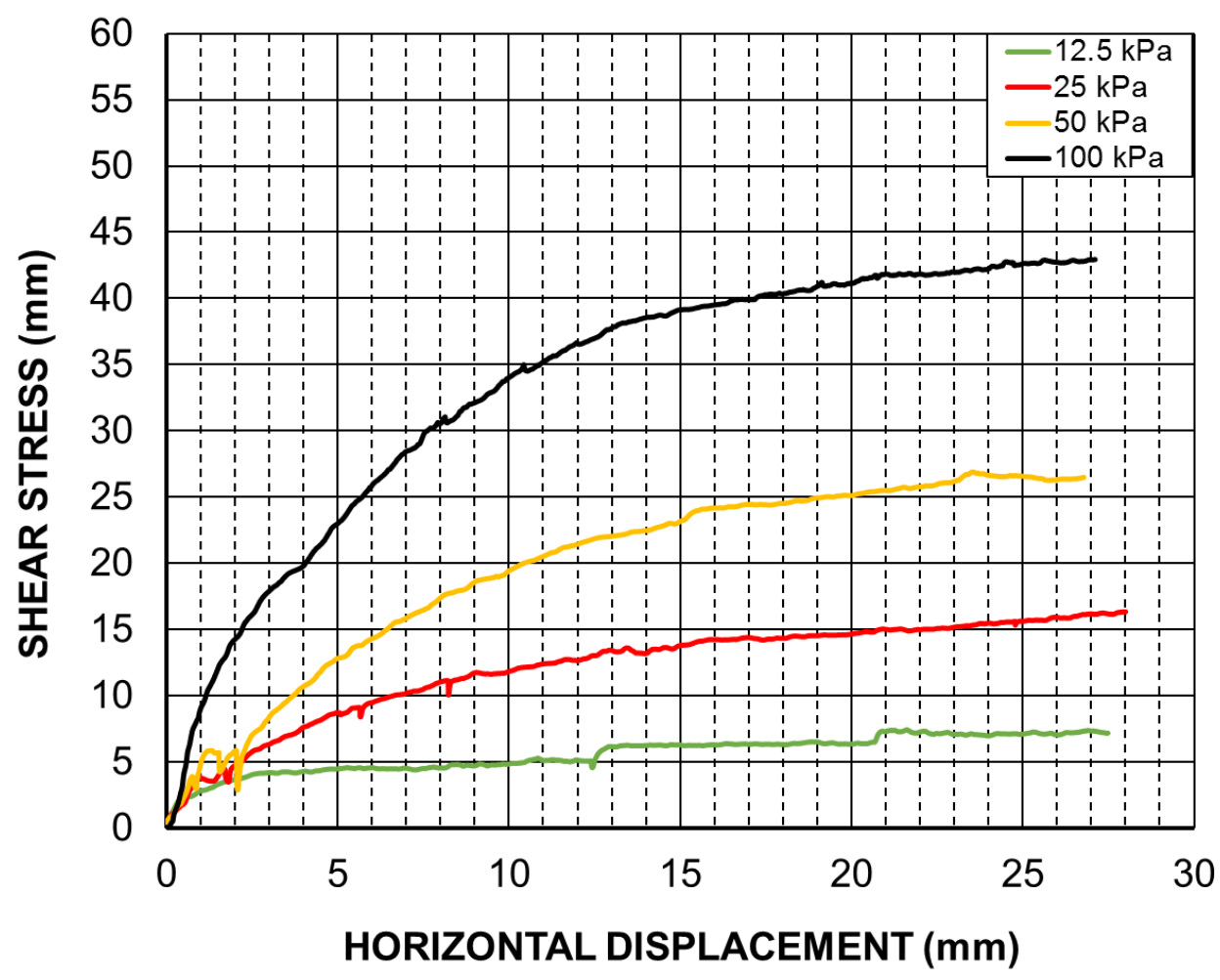

Fig.8c. Shear stress-horizontal displacement behaviour of MS-kaolin geocomposite

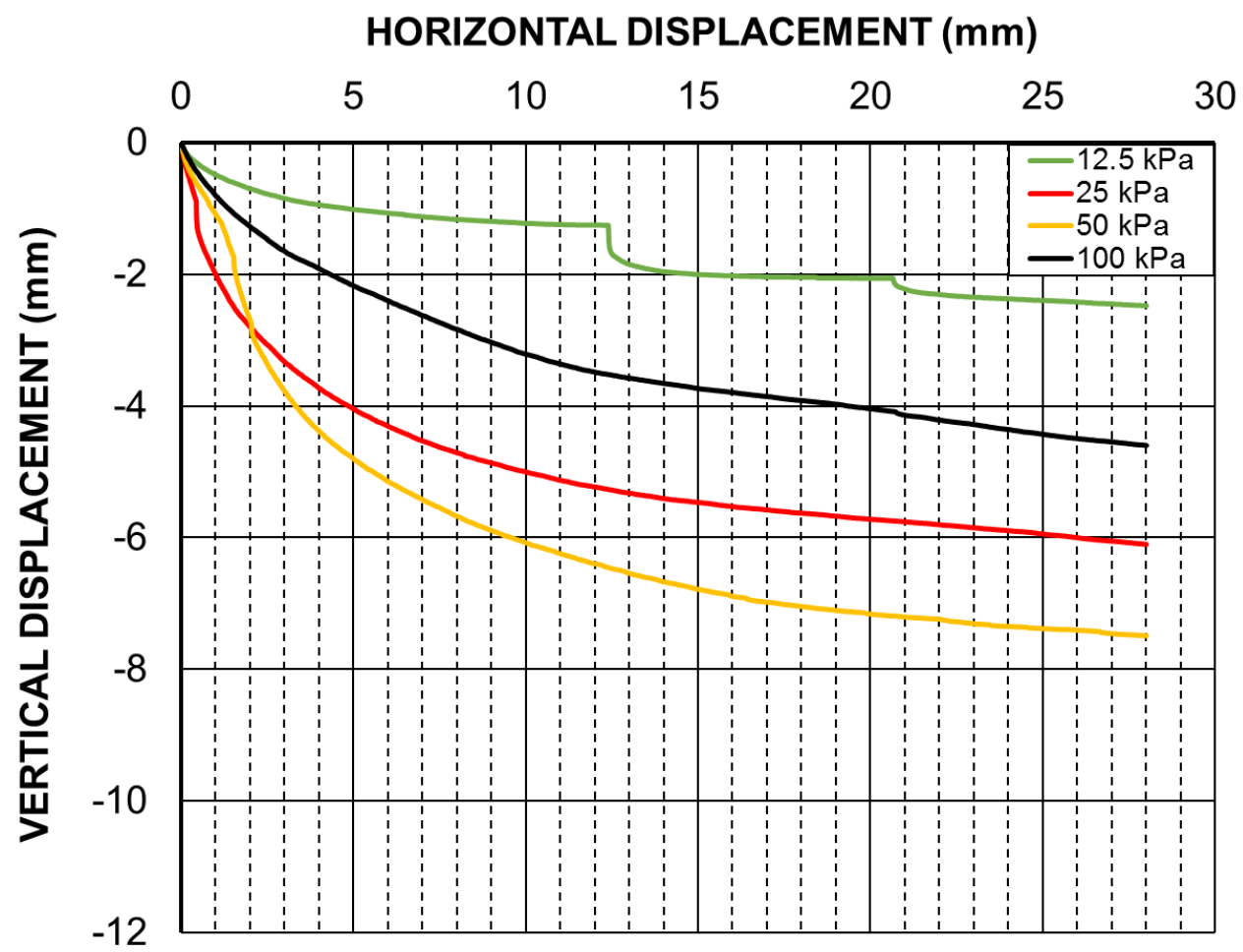

Fig.9c. Horizontal-vertical stress displacement behaviour of MS-kaolin geocomposite 


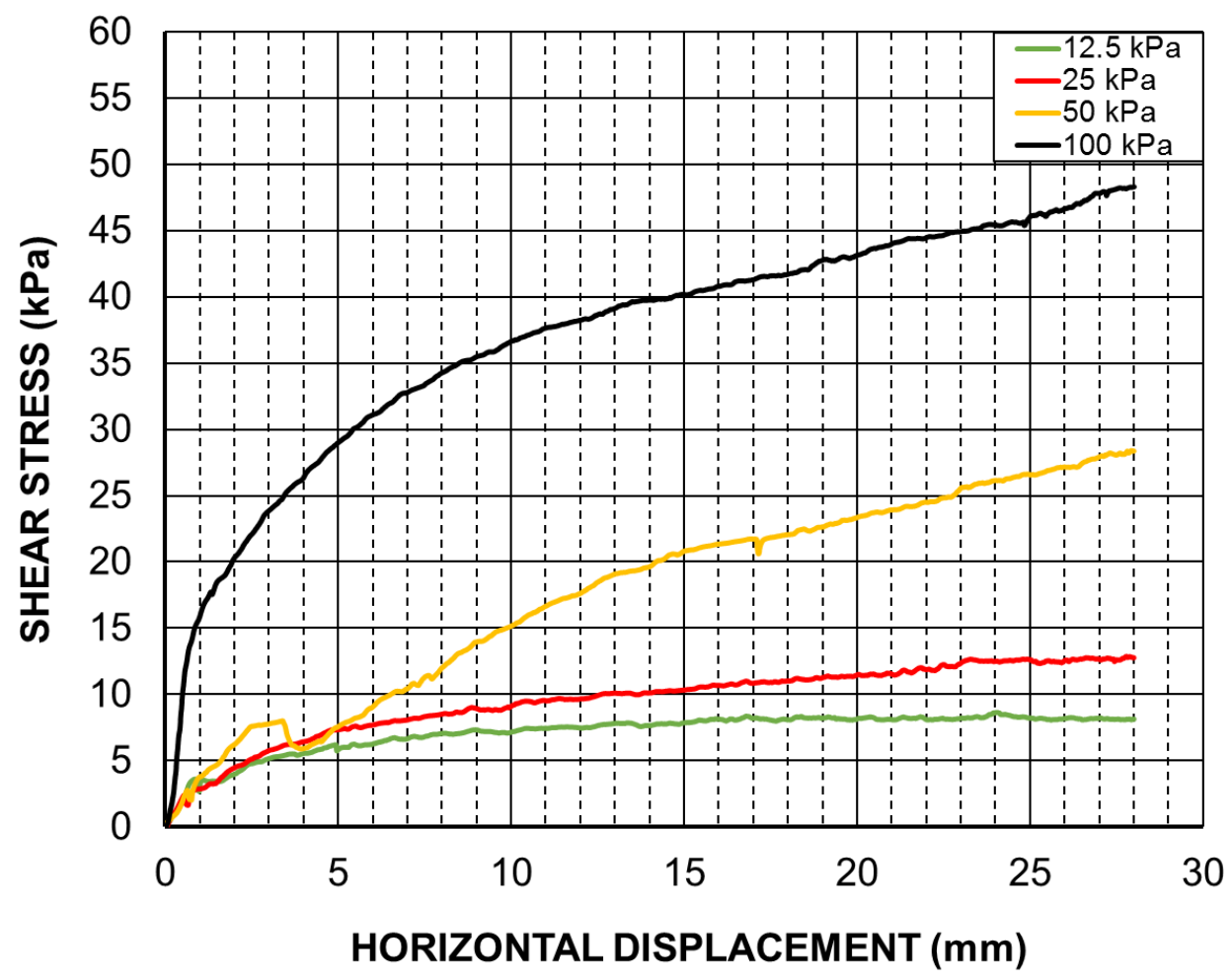

Fig.8d. Shear stress-horizontal displacement behaviour of CWG-kaolin geocomposite

\section{HORIZONTAL DISPLACEMENT (mm)}

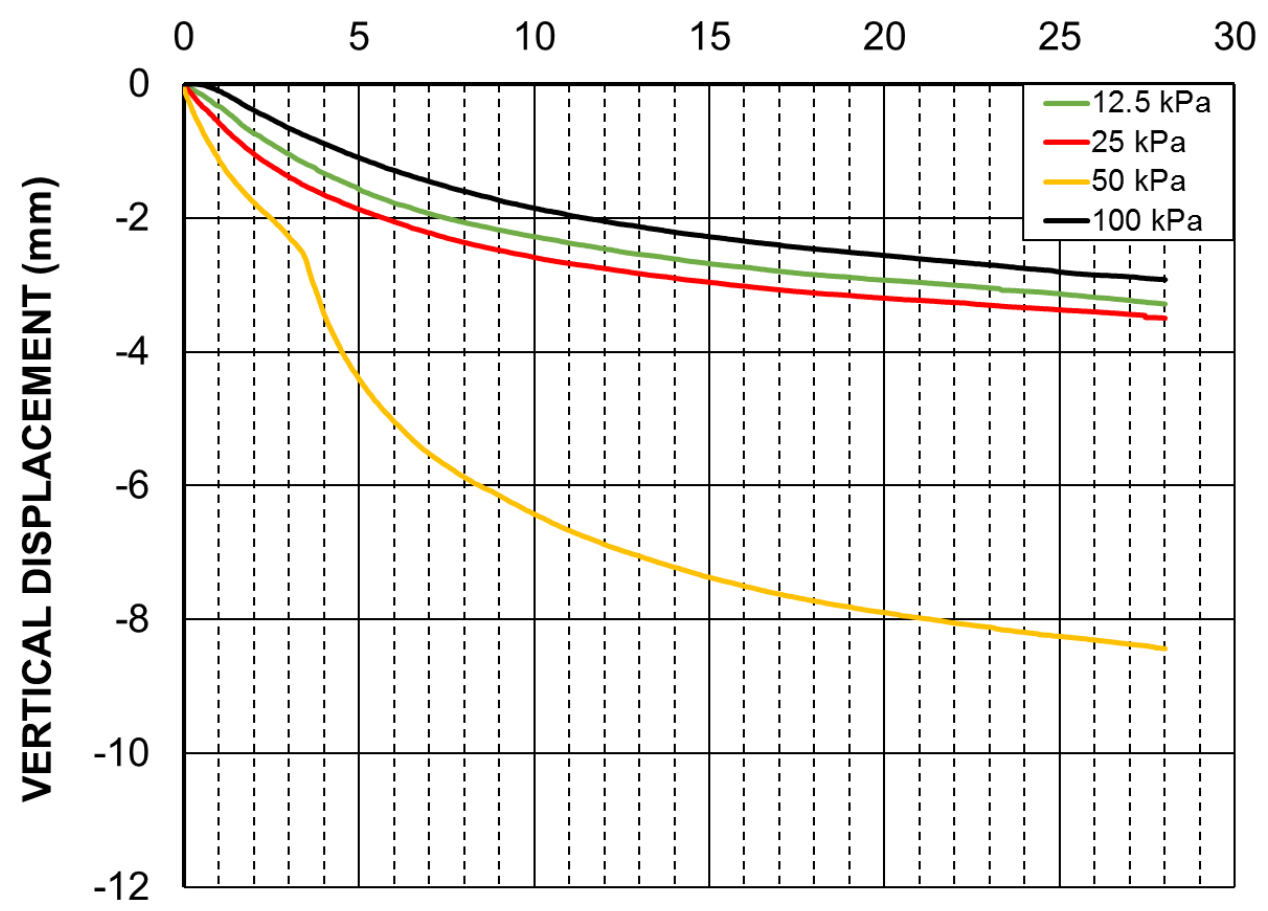

Fig.9d. Horizontal-vertical stress displacement behaviour of CWG-kaolin geocomposite 


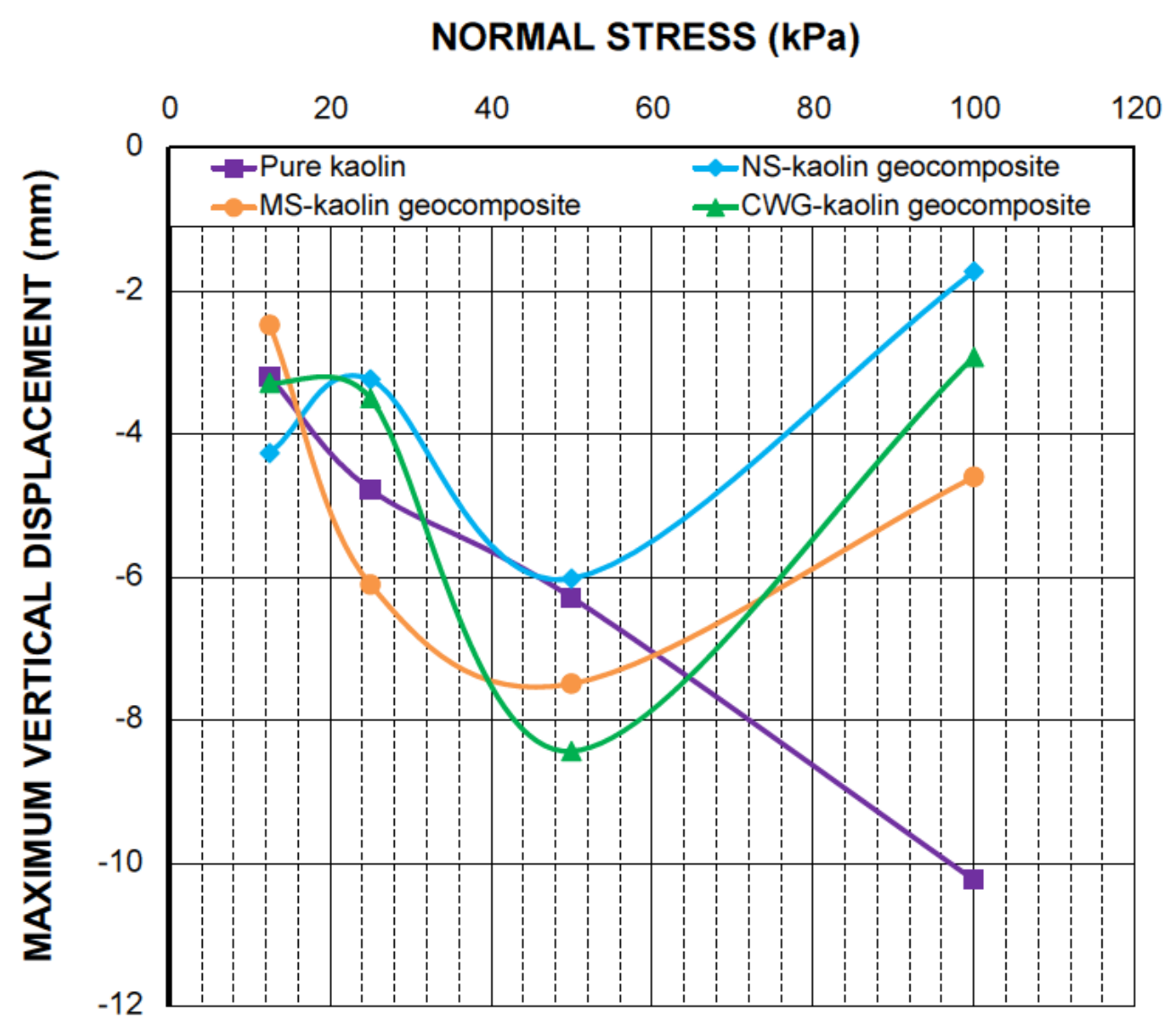

Fig.10. Maximum vertical displacement-normal stress behaviour of the specimens
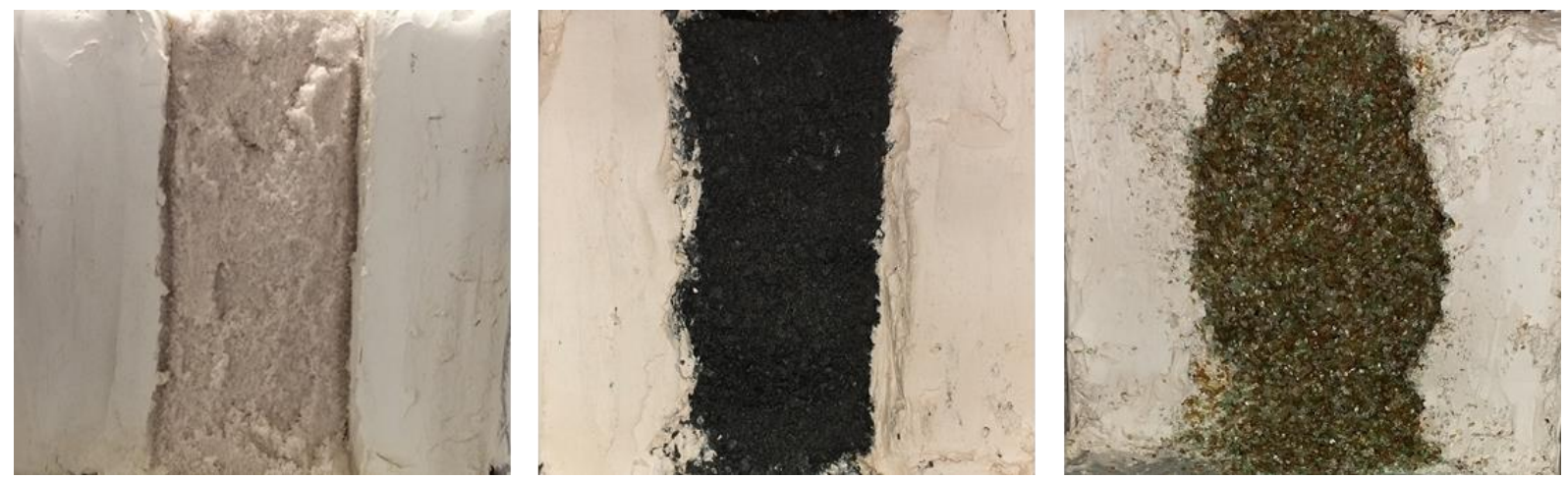

Fig.11. Post-shearing cross-section of the geocomposites under $25 \mathrm{kPa}$ normal stress (NS-kaolin, MSkaolin and CWG-kaolin geocomposite from left to right) 